\title{
A theory of regional conflict complexes
}

Arthur Silve

Thierry Verdier

Mars / March 2018 


\title{
A theory of regional conflict complexes
}

\author{
Arthur Silve* \\ Thierry Verdier ${ }^{\dagger}$
}

March 24, 2018

\begin{abstract}
Civil conflicts spill over into neighboring countries. This paper proposes a theory of the contagion of civil wars. Weak territorial control facilitates the emergence of a regional market for war inputs in the "porous frontier." The contagion effect is nonlinear and creates multiple equilibrium situations of regional complexes of civil conflicts. This helps explain the observed patterns of regional clustering of conflict and institutional quality, and raises identification issues in the measurement of the contagion effect. We also derive a positive spillover of civil wars: governments are sometimes in a position to avoid contagion by improving their institutions. Finally, we explore the policy implications for military intervention, and military and institutional cooperation.
\end{abstract}

Keywords: civil war, contagion, porous frontier, institutions, military intervention, institutional cooperation

JEL classification: D74, N40, P48

\section{Introduction}

On January 16, 2012, The National Movement for the Liberation of Azawad (MNLA), an organization fighting to make Azawad in Northern Mali an independent homeland for the Tuareg people, started a rebellion against the Malian government. Taking advantage of an internal political crisis in the country (the ousting of the incumbent President Amadou Toumani Touré), the MNLA quickly overran the three largest northern citiesKidal, Gao and Timbuktu, and on April 6, 2012 proclaimed Azawad's independence. Islamist groups, such as Ansar Dine, who had initially backed the MNLA, later turned

\footnotetext{
*Université Laval. Email: arthur.silve@ecn.ulaval.ca. Address for correspondence: Pavillon J.-A. DeSève 2264, 1025 Avenue des Sc.-Humaines, Québec, G1V 0A6, Canada.

†PSE and École des Ponts-ParisTech, PUC-Rio, CEPR. Email: thierry.verdier@ens.fr. Address for correspondence: 48 Boulevard Jourdan, 75014 Paris, France.
} 
against the MLNA in order to impose strict Sharia law in the Northern territories. By mid-July 2012, these Islamic groups gained control of most of northern Mali's cities and started moving towards the capital, Bamako. The Malian government managed to stop them and recover the Northern territories in the beginning of 2013, with the support of an international coalition, led by the French military and African Union states.

The 2012 insurgency in northern Mali was associated with a series of historical factors related to the domestic political situation in Mali. Due to economic hardships and longstanding political marginalization by the Southern governments in Bamako, the Tuareg people had already unsuccessfully rebelled in 1962, 1990, and 2007. Recurrent episodes of local droughts and food shortages also tended to exacerbate social tensions and to encourage revolts. Domestic factors however do not give a full account of the 2012 insurgency. Several observers also noted that it was connected to the broader regional context, and in particular to the Libyan Civil War (which culminated in late 2011, see DiCarlo, 2012; Ban, 2012). Specifically, collapsing state order in the whole Sahel and Sahara region enabled a number of cross-border destabilizing factors, such as a large number of traumatized and impoverished returnees, trained ex-soldiers and mercenaries released from the Qaddafi regime, ${ }^{1}$ and an unspecified amount of weapons and ammunition from the Libyan arsenal all flowing into the region.

The example of the 2012 insurgency in Mali reflects a general pattern of conflicts in the world: civil wars and state failures tend to cluster in time and space. Beside Mali, other examples abound, from the Balkan countries and Central Asian region after the fall of the Communist block, to the Great Lakes region in Central Africa, the Horn of Eastern Africa, and recently the Arab Spring wave in the Maghreb and the Middle East.

The Malian case also illustrates the fact that both domestic and regional contextual variables are plausible factors explaining the spatial pattern of civil conflicts. On the one hand, similarities between neighboring countries suggest that regional clusters of civil wars result from the clustering of similar domestic attributes (geographical or social characteristics, resource endowments, and climatic conditions). ${ }^{2}$ On the other hand, the discussion of the broader regional context typically emphasizes cross-borders spillovers and conflict diffusion as crucial determinants of the spatial distribution of civil wars. In line with this second view, Salehyan \& Gleditsch (2006) report for instance that a conflict in a neighbor increases the odds of an intrastate conflict by about $52 \%$. Buhaug \& Gleditsch (2008) find a comparable figure of $44 \%$ (keeping the country-specific attributes usually emphasized in the comparative civil war literature constant). Braithwaite (2010) also finds significant marginal effects of a neighboring conflict.

${ }^{1}$ According to the International Organization for Migration, 420,000 people fled Libya, 30,000 of whom returned to Mali (Ban, 2012, p. 6). These migrants included Tuareg combatants who aided the Qaddafi regime and returned to Mali trained and armed. Mohammed Ag Najim is a notable example: a former colonel in Qaddafi's army, he became the head of the MNLA.

${ }^{2}$ See for instance Hegre et al. (2001); Elbadawi \& Sambanis (2002); Gleditsch (2002); Fearon \& Laitin (2003); Collier \& Hoeffler (2004); Bosker \& de Ree (2014). 
While the literature recognizes both domestic and diffusion factors, scholars typically study them as if they were independent and alternative sources of instability. This approach neglects regional interactions and feedback effects across countries, as well as linkages between internal and regional factors of conflicts. Although convenient, this view reflects the lack of a model articulating how patterns of civil wars can be the outcome of joint processes at the regional level. As discussed by Gersovitz \& Kriger (2013), it may also generate serious endogeneity issues in empirical analyses.

The purpose of this paper is to provide the first theoretical framework that highlights such systemic considerations in general equilibrium. It shows the interaction and complementarity between internal factors (locally correlated or not) and diffusion mechanisms, and the destabilizing effects at a regional level.

Our starting point is a simple one-country model of civil conflict and repression, largely inspired by the specification in Azam (2006). In each country, the group in power (the government) is able to exploit a resource which may be disputed by another group (the challenger). Fighting over the resource is costly to all parties: the challenger may prefer not to dispute the control of the resource, and the government may discourage a rebellion, thanks to two instruments: redistribution and deterrence. Redistribution corresponds to a transfer that rewards the other group's peaceful behavior. Deterrence is obtained through investment in a warfare technology that raises the cost of fighting for the challenger. The political regime is determined by two domestic factors of interest: the opportunity cost of fighting for the challenger, and the ability of the government to commit to resource sharing. Civil conflict occurs for low opportunity costs and low government credibility. When either one increases, the domestic political outcome is likely to turn to peace, and the government to favor redistribution over deterrence.

We extend this model to two countries, explicitly taking into account the conflict contagion mechanism across borders. Specifically we emphasize the role of underground agents that facilitate conflict (Wolff, 2010; DCAF \& Geneva Call, 2011; Cunningham et al., 2013, 2016), such as warlords, terrorist organizations, organized crime (Mincheva \& Gurr, 2010a,b, 2013; Hübschle, 2011), weapon traffickers and brokers, and we focus our attention on the market for violence. Rebels constitute the demand-side of that market, while underground agents, the so-called "problems without passports" (Picciotto et al., 2005), supply them with war inputs (weapons, small arms, ammunition, mercenaries and logistics). Such an underground sector thrives at the porous frontier between countries, in territories that escape the control of formal governments. Its efficiency depends on the size of the market for violence. This creates a natural channel for the cross-border diffusion of civil conflict at the regional level. Domestic violence in one country has implications for the political economy of domestic violence in the other country, and the domestic and diffusion factors of conflict are complements.

The model yields three main results. Primarily, national political regimes are strategic complements at a regional scale. The incentives for one national government to 
conciliate a rebel group are positively affected by a peaceful social settlement in the neighboring country. This feature leads to a joint determination of regional political regimes that depends on the domestic factors in both countries. Importantly, the feedback effects associated with this interaction make multiple regional equilibria possible. From a given set of domestic factors, civil wars can erupt in both countries, or they can both be at peace. Because of strategic complementarities in their domestic political incentives, countries in the same regional complex may thus end up in very different situations for the same observable fundamentals. From an empirical point of view, this feature highlights the importance of taking a regional perspective on civil conflicts. Looking at countries only as separate units subject to an exogenous diffusion process misses feedback mechanisms and the role of local expectations in the formation of regional clusters of civil wars. Not controlling for these typically unobservable (possibly time-varying) dyadic dimensions may thus lead to biased estimates of diffusion effects. From a policy perspective, a fully endogenous regional approach highlights the crucial coordination role that regional institutions could have on national policies to avoid regional clusters of civil conflicts.

A second contribution of our analysis is to highlight how civil war clustering translates into institutional clustering at the regional level. More precisely, a government's incentive to invest in institutions (ie. the ability to uphold property rights and to credibly commit to a certain policy regime), depends on its neighbor's degree of institutional fragility, and on the size of the potential spillover effects associated with civil conflicts. Large spillovers of civil conflicts abroad result in negative incentives to invest in domestic institutions (i.e. a negative institutional spillover). Conversely, consistent with Braithwaite (2010) and McBride et al. (2011), small conflict spillovers motivate a government to invest in better institutions, to avoid contagion of the neighboring conflict (i.e. a positive institutional spillover). More generally speaking, we argue that the contagion of civil conflict favors a spatial clustering of institutional quality as well.

Third, our model naturally provides a framework to investigate motives for external intervention. Such an intervention may take different forms: international aid and institutional cooperation, military intervention, or military assistance. Every type of intervention is costly, but intervening may prevent a civil war from erupting abroad, and the associated threat of contagion. Below a cost threshold, a government intervenes in a fragile neighbor to lower the odds of having to deal with its own rebels.

The outline of the article is as follows. The next section briefly examines the related literature. Section 3 introduces the market for violence, and defines the various feasible political regimes in the case of an isolated country. Section 4 extends the analysis to the case of two countries interconnected by a common market for violence operating at their porous frontier. Section 5 considers investment in institutions as endogenous, and uncovers how spillovers of conflict translate into institutional spillover effects. Section 6 explores the ways a government may intervene to avoid a civil war in its neighbor 
to prevent the threat of contagion. We also discuss the implications of the model for domestic, regional, and international responses using the rise of AQIM in Mali, ISIL in Syria and Iraq, and civil unrest in Morocco. Section 7 concludes.

\section{Related literature}

Our paper naturally relates both to the literature on the country-level determinants of civil conflicts (see Sambanis, 2002, and Blattman \& Miguel, 2010, for a detailed review of the literature), and to the literature on the cross-border contagion effects of civil wars (see Anselin \& O’Loughlin, 1992; Gleditsch, 2002, 2007; Braithwaite, 2006; Hegre \& Sambanis, 2006; Black, 2013). ${ }^{3}$ Our analysis focuses on how the interaction of these two sets of factors matters for the spatial distribution of civil conflicts.

Our framework emphasizes the importance of conflict regimes regional interdependence and feedback effects and therefore provides an analytical illustration of the notion of "regional security / war complexes" as expounded by Lemke (2002); Buzan \& Wæver (2003); Rubin (2006) and Ansorg (2011) in the international security literature.

Our motivation for civil conflict spillovers builds upon the literature on the micro channels of cross-border contagion effects. Specifically, our focus on the existence of violent underground actors and active markets for violence at the porous borders of regional conflicts is consistent with Rubin (2001); Armstrong \& Rubin (2005); Wolff (2010); DCAF \& Geneva Call (2011); Michalopoulos \& Papaioannou (2014); Cunningham et al. (2016) and with the fact that the cross-border proliferation of small arms is widely recognized as a major element of regional instability. ${ }^{4}$

The interaction between institutions and conflict also relates to the wide literature on state capacity and institution building. With a narrow definition of state capacity as the capacity to raise taxes, Tilly (1985); Levi (1988) and Brewer (1989) argue that war was key in the development of European states. Conversely, Besley \& Persson (2008, 2009, 2010) provide models of the investment in fiscal / legal state capacity in which the risk of a civil war is a negative determinant of state capacity (also see Bourguignon \& Verdier, 2009; Cárdenas \& Tuzemen, 2011). Our focus is rather on property rights protection (Jones, 1981; De Long \& Shleifer, 1993; Acemoglu et al., 2001) and, more specifically, institutions that are key in the formulation of credible policies (Besley \& Ghatak, 2010). Our concept of institutions therefore includes all the institutional infrastructure that promotes the credibility of policy promises: good governance procedures, checks and balances and constraints on the executive, state administrative capacity, or bureaucratic

\footnotetext{
${ }^{3}$ Chauvet \& Collier (2004) also highlight the importance of cross-border economic effects associated with the proximity to a low-income country under stress (LICUS).

${ }^{4}$ See for instance the systematic analyses of changing trends in small arms trafficking provided by the project Small Arm Survey project at http://www.smallarmssurvey.org/publications/bytype/yearbook.html.
} 
norms. We explicitly analyze the interdependent incentives of governments to invest in national state institutions, given their regional cross border conflict connections.

The policy implications on the benefits of regional coordination at the policy / institutional level connect well to the development policy literature emphasizing the regional dimension of state fragility. ${ }^{5}$ They also relate to the international relations literature which argues that a state may improve its domestic commitment capacity through international audience costs: international agreements and multilateral supervision help the government signal its commitments to its own population (Keohane, 1984). ${ }^{6}$ Our discussion of military intervention is also consistent with the findings of Kathman (2010, 2011) showing that a state may help a neighbor quell a rebellion, in order to avoid a possible contagion effect.

\section{Deterrence, redistribution and the market for violence}

We first lay out a simple political economy model of civil conflict for a given country, based on Azam (2006). The economy is composed of two groups, indexed by $G$ and $C$, (for Government and Challenger, respectively), with each group behaving as a unitary agent. The two groups may contest a resource $R$ and invest respectively $M_{G} \geq 0$ and $M_{C} \geq 0$ in the conflict. Following Azam (2006), the technology of conflict is described by the probability of the government being overthrown:

$$
\begin{aligned}
\Pi & =1, \text { if } \gamma M_{C} \geq M_{G} \text { and } M_{G}<\bar{M} \\
& =\pi, \text { with } 0<\pi<1, \text { if } \gamma M_{C} \geq M_{G} \geq \bar{M} \\
& =0, \text { if } \gamma M_{C}<M_{G}
\end{aligned}
$$

Parameter $\gamma$ represents the fighting efficiency of group $C$ relative to the government. $C$ is more efficient at fighting than $G$ if $\gamma>1$, and less efficient otherwise. This parameter characterizes the warfare technology, which is relatively favorable to the government or to a guerrilla, the terrain conditions, the degree of political mobilization, or the morale in the army. Parameter $\bar{M}$ captures a scale effect in the government's defense technology. A minimum defense expenditure is required, to avoid being ousted by a challenger. Parameter $\pi$ captures the probability that conditional on there being a rebellion, it will be successful. $\pi$ therefore captures a certain degree of contextual effectiveness of the rebel group once in conflict. It can be affected by the conditions of

${ }^{5}$ See for instance for West Africa Vallings \& Moreno-Torres (2005); Moreno-Torres \& Anderson (2004), and for the African Great Lakes region OECD (2004).

${ }^{6}$ For instance Mansfield \& Pevehouse (2006) show that international organizations help governments signal their commitment to democratization, and Böhnke \& Zürcher (2013) that aid helps support a state's legitimacy. 
the warfare technology and notably by the fact that rebels have access to weapons and mercenaries.

To challenge the government, a rebel group needs war inputs, such as small arms and light weapons (assault rifles, pistols, machine guns, grenades, rocket launchers, or land mines), parts and components, accessories and ammunition, as well as mercenaries, security services, and logistical support. These inputs are supplied by a variety of agents, whether officially and unofficially state-sponsored organizations, private intermediaries, criminal organizations, or local cross-border ethnic communities involved in the trade, transportation, or stocking of weapons and associated services (Seniora \& Poitevin, 2010; Zohar, 2014). This underground trafficking sector typically develops in safe haven zones where weakly institutionalized states cannot impose their monopoly of violence and order (porous borders).

As acknowledged by several observers, the supply side and the market structure of the underground warfare sector vary widely. Indeed, considerable differences exist between traffickers, from the types of weapons and methods of concealment to their volume and sophistication (Stimson Center, 2016; May, 2017). At one end of the spectrum, sophisticated transnational illicit arms brokers with well-connected networks, such as Viktor Bout (see next paragraph), Leonid Minin or Monser al Kassar, cater to governments and to rebel groups, and tend to move large consignments. Often at an intercontinental scale, these arms brokers invest in considerable logistics infrastructure (transportation, stockpiling, financing, security, bribing and networking), to intermediate and bargain with buyers and sellers under a layer of anonymity and protection. They tend to operate on the secondary market and to divert legal supplies by illegal means (i.e., illicit transfers) and corruption networks (Bichler \& Malm, 2013; Zohar, 2014). At the other end of the spectrum, a good percentage of arms trafficking also takes place through numerous small-scale local transactions, known as the "ant trade," by individuals and loosely-affiliated networks involving smaller-scale logistics infrastructure (Stimson Center, 2016). Likewise, while industrial manufacturing is performed through companies on a large scale and tends to produce high-quality products, craft production commonly involves the local fabrication of lower-quality weapons by hand in limited quantities.

In the main text, we consider a model best exemplified by the infamous "merchant of death" Viktor Bout, ${ }^{7}$ with a war input supplier engaging directly in monopolistic bargaining with rebel groups, and spending significant resources in logistics infrastructure

${ }^{7}$ Viktor Bout is a former Soviet military officer, who became a global arms trafficker. In the late 1990s, he was running a private fleet of more than 60 long-haul cargo planes, spanning the globe from Africa to Afghanistan, with bases in Belgium, South Africa, Swaziland, the United Arab Emirates, and across Eastern Europe. He was a key provider of assault rifles and more sophisticated weapon systems in the violence-plagued African nations of Liberia, Angola, Sierra Leone and the Democratic Republic of the Congo. He received abundant media coverage as he inspired the film "The Lord of War" starring Nicolas Cage. See http://www.telegraph.co.uk/news/worldnews/europe/russia/11005783/ViktorBout-arms-dealer-Lord-of-War-and-home-movie-buff.html. 
to improve the efficiency of his global illegal activities. In the Appendix, we describe an alternative version with monopolistic competitive suppliers, which better captures the stylized context of many small scale local suppliers and traffickers of craft production of war inputs. The two markets $s$ of the underground sector provide the same qualitative implications for cross-border spillover effects and the diffusion of civil conflicts in the region.

Specifically, we consider the case of a global war input supplier / broker who provides an undifferentiated war input entering explicitly in the technology of conflict between rebels and the government. We consider the following specification:

$$
\pi=\pi(w)=\pi_{0}+\left(1-\pi_{0}\right)\left(1-e^{-w}\right)
$$

where $w$ is the amount of the war input. ${ }^{8}$ The cost to supply one unit of the war input is assumed to be $c(I)$, which depends on the quality of logistics infrastructure $I$ undertaken by the supplier / broker. $c(\cdot)$ is assumed to be decreasing and convex in $I$. As said above, I may account for a network of weapon transportation and stockpiling, for the financial infrastructure that provides a layer of anonymity for illegal arms transactions and allows the diversion of legal supplies by illicit transfers, for a security force for the protection of traders and merchandises, or for a corruption network with officials who facilitate the diversion of official inventories of military weapons. $I$ comes at a cost $\phi(I)$, with $\phi$ increasing and convex in $I$, which corresponds to building and maintaining the transportation and corruption networks, investment in financial infrastructure, and for the cost of the security force.

As will become clear below, the contestable resource $R$ should be large enough relative to the marginal cost of investment for investment to make sense. A sufficient condition is that $\left(1-\pi_{0}\right) R \geq c(0)$. We will assume that this is the case thereafter.

Both $G$ and $C$ can allocate the labor endowments $N_{G}$ and $N_{C}$ between production and conflict. The output levels of the two groups are very stylized:

$$
Y_{G}=N_{G}-M_{G} \text { and } Y_{C}=a\left(N_{C}-M_{C}\right)
$$

$N_{G}$ and $N_{C}$ are the resources available to each group, and $M_{G}$ and $M_{C}$ the resources they respectively invest in the conflict. The government remains in control of the contestable resources $R$, unless it is overthrown. In that case, the control of the resources shifts to the other group. $R$ may account for instance for the revenue from mineral extraction, which accrues to the group in power. Parameter $a$ represents the productive efficiency of group $C$ relative to the government. $C$ is more efficient at producing if $a>1$, and less efficient otherwise. $a$ depends on the relative productivity of each group, but also on the relative prices they face, when the government and the challenger face different trade shocks.

${ }^{8}$ The parametric specification is chosen for analytical convenience. What matters is the fact that $\pi$ is an increasing concave function of the war input $w$. 
The game takes place in the following stages:

1. The government first invests irreversibly $M_{G} \geq 0$, and offers the other group a social contract, which consists of a transfer $T \geq 0$ conditional on the other group not entering into conflict: $\Pi=0$, which comes down to $\gamma M_{C}<M_{G}$.

2. The challenger invests $M_{C} \geq 0$.

If $\gamma M_{C} \geq M_{G}$, the game continues as follows:

3. The weapon broker / supplier enters the market to supply a war input $w$, investing in logistics infrastructure $I$.

4. The weapon broker / supplier and the rebel group bargain on the amount $w$ of war inputs to be provided and on the payment $p$ to be made by the rebel group. The civil war erupts and its issue is decided.

Otherwise:

3'. the government transfers $T$ with probability $\theta$ (for now, given exogenously). $\theta$ measures the quality of property rights protection

Finally, production and consumption take place.

With $\chi$ the characteristic function of peace, the two groups derive the following payoffs:

$$
\left\{\begin{array}{l}
U_{G}=N_{G}-M_{G}+(1-\Pi) R-\theta \chi T \\
U_{C}=a\left(N_{C}-M_{C}\right)+\theta \chi T+\Pi R-(1-\chi) p
\end{array}\right.
$$

In a reduced form, these payoffs capture the essence of the redistributional stakes of civil conflicts in developing countries endowed with natural resources. Notice that $\theta$ captures a narrow definition of property rights protection: the credibility of the state's rent-sharing commitment. We do not account for other dimensions such as fiscal or legal capacity, as for instance emphasized by Besley \& Persson (2009) and their impact on the two groups' economic incentives.

The government is subject to a budget constraint (BC): it can never credibly promise more than what it produces in times of peace:

$$
N_{G}+R-M_{G}-T \geq 0
$$

Let us now turn to the challenger's incentive constraint. To simplify we assume that the minimum deterrence level $\bar{M}$ is small enough for the government to always have an 
incentive to invest $M_{G} \geq \bar{M} \cdot{ }^{9}$ Investing in military capacity helps achieve a peaceful outcome and deter an unruly group from contesting $R$, and if a conflict does erupt, this reduces the probability of losing the resource from 1 to $\pi$.

The model is solved by backward induction. The production and consumption stages are trivially resolved. Then, it is straightforward to see that if the challenger accepts the peaceful contract in stage 2, they do not put any resource in the conflict and $M_{C}=0$. In that case, there is no civil war.

If stage 2 results in a civil war, the problem of the rebel group requires more careful consideration. We assume the negotiation between the rebels and the weapons broker to be determined by a standard Nash bargaining solution $\left(w^{N}, p^{N}\right)$. When the rebel strikes a deal with the weapons broker, the expected payoff is $a\left(N_{C}-M_{G} / \gamma\right)+\pi\left(w^{N}\right) R-p^{N}$. Otherwise it is $a\left(N_{C}-M_{G} / \gamma\right)+\pi_{0} R$. Meanwhile, the broker gains $p^{N}-c(I) w^{N}$ from bargaining with the challenger and 0 otherwise. The bargaining outcome maximizes the Nash Product $\left(\left(\pi(w)-\pi_{0}\right) R-p\right)(p-c(I) w)$. The solution to that maximization problem can be written:

$$
\left\{\begin{array}{l}
w^{N}(I)=\ln \left(\left(1-\pi_{0}\right) R / c(I)\right) \\
p^{N}(I)=\left(\left(1-\pi_{0}\right) R-c(I)+c(I) w^{N}(I)\right) / 2
\end{array}\right.
$$

In equilibrium, the likelihood of a rebellion being successful is $\pi\left(w^{N}(I)\right)=1-c(I) / R$. It increases with the level of logistics infrastructure $I$ and with the size of the contested resource $R$. Under conflict, the expected utility of the rebels can therefore be written $U_{C}=a\left(N_{C}-M_{G} / \gamma\right)+\Gamma(I)$, with $\Gamma$ an increasing function of $I .{ }^{10}$

$$
\Gamma(I)=\frac{\left(1+\pi_{0}\right) R}{2}-c(I) \cdot \frac{1+\ln \left(\frac{\left(1-\pi_{0}\right) R}{c(I)}\right)}{2}
$$

The weapons broker maximizes $p^{N}(I)-c(I) w^{N}(I)-\phi(I)$. Under concavity of this maximization problem, ${ }^{11}$ the first order condition defines implicitly the optimal level of investment $I^{*}(R)$, with $I^{*}$ increasing in $R:{ }^{12}$

${ }^{9}$ In the case of a civil war, the government maximizes $N_{G}-M_{G}+(1-\Pi) R$ with $\Pi=1$ if $M_{G}<\bar{M}$, and $\Pi=\pi(w(I))$ otherwise, where $I$ is the equilibrium investment by the non-state actor. In the case of peace, the government maximizes $N_{G}-M_{G}+R-\theta T$ subject to the incentive constraint. As long as $\left(1-\pi_{0}\right) R \geq \bar{M}$, it is worth investing $M_{G} \geq \bar{M}$ in both cases. Even in the case of peace, the government invests $\bar{M}$ in conflict technology, so as to deter a rebellion.

${ }^{10} \Gamma(I)=\left(1+\pi_{0}\right) R / 2-c(I)\left(1+\ln \left(\left(1-\pi_{0}\right) R / c(I)\right)\right) / 2$. Since $\left(1-\pi_{0}\right) R / c(I)>\left(1-\pi_{0}\right) R / c(0)>1$ and $c^{\prime}(I)<0$, we have $\Gamma^{\prime}(I)=-c^{\prime}(I) \ln \left(\left(1-\pi_{0}\right) R / c(I)\right) / 2>0$.

${ }^{11} \mathrm{~A}$ sufficient condition is that $c(\cdot)$ is such that

$$
\forall I,-c^{\prime \prime N}(I)+c^{\prime 2}(I) / c(I)<0
$$

${ }^{12}$ Since $p^{N}(I)-c(I) w^{N}(I)-\phi(I)$ is supermodular in $(I, R)$, Topkis's theorem establishes that $I^{*}$ increases with $R$. 


$$
c^{\prime N}(I)+2 \phi^{\prime}(I)=0
$$

We can finally turn to stage 1 . For a given level $I=I^{*}(R)$ of logistics infrastructure (in case of a civil conflict), the challenger accepts the social contract if and only if their utility under the social contract with uncertain transfer exceeds their expected utility in a civil war, i.e.

$$
\theta T \geq \Gamma(I)-\alpha M_{G}
$$

The left-hand side of this condition is the transfer expected from the government if it accepts the contract. The right-hand side of this condition is the expected gain from civil war. Parameter $\alpha=a / \gamma$ represents the comparative advantage of the challenger at producing vs. fighting. Intuitively, $\alpha$ is a proxy for the opportunity cost of conflict for group $C$, in terms of the foregone production. The transfer necessary to ensure that $C$ accepts the contract is lower for higher values of $\alpha$ and $M_{G}$, and lower values $R$. On the one hand, the amount of resources $R$ available increases the temptation of conflict, and the more likely a rebellion is to succeed, the more costly it is for the government to discourage it. On the other hand, the higher the opportunity cost of conflict $\alpha$ and the resources invested in warfare technology $M_{G}$, the less tempting a conflict is, and the less costly it is for the government to discourage it.

Jointly, (BC) and (IC) define the set of feasible contracts. The optimal peaceful contract for the government results from the following program:

$$
\begin{gathered}
\max _{M_{G}, T} N_{G}-M_{G}+R-\theta T \\
\text { s.t. } \begin{cases}N_{G}-M_{G}+R-T \geq 0 \quad(\mathrm{BC}) \\
\theta T \geq \Gamma(I)-\alpha M_{G}\end{cases}
\end{gathered}
$$

When no peaceful contract is feasible, the government is forced into a civil war; additionally, there are cases in which the government favors a civil war over the peaceful alternative. This linear programming problem is solved by Azam (2006) (albeit in a simpler framework). In Appendix A, we provide a formal characterization of the different regimes. Specifically, for a given logistics infrastructure $I$, we show that we can rely on two threshold curves:

$$
\bar{\theta}(I, \alpha)=\frac{\Gamma(I)-\alpha \bar{M}}{R+N_{G}-\bar{M}} \quad \text { and } \quad \underline{\theta}(I, \alpha)=\frac{\Gamma(I)-\alpha(R+\bar{M}-c(I))}{N_{G}-\bar{M}-\alpha\left(N_{G}+R\right)+\Gamma(I)+c(I)}
$$

to separate the different equilibrium political regimes in terms of parameters $\alpha$ and $\theta$. This is illustrated in Fig. 1. As shown on the figure, when the opportunity cost of conflict $\alpha$ is below 1 , the thresholds $\bar{\theta}(I, \alpha)$ and $\underline{\theta}(I, \alpha)$ define different political equilibrium regimes: below $\underline{\theta}(I, \alpha)$ a civil war erupts, above $\bar{\theta}(I, \alpha)$ the government implements 
a redistributive regime, while between the two curves $\bar{\theta}(I, \alpha)$ and $\underline{\theta}(I, \alpha)$, there is a repressive peaceful regime. In the region with $\alpha \geq 1$, the government establishes a pratorian regime in which the government obtains peace through repression without any transfer $(T=0)$. This last regime is less relevant in our discussion, and we will assume that $\alpha<1$ from now on.

More precisely, when $\theta \geq \max \{\bar{\theta}(I, \alpha), \underline{\theta}(I, \alpha)\}$ and $\alpha<1$, the redistributive political regime corresponds to a state that ensures peace, relying on a transfer to the other group, and without resorting to military deterrence. Military spending is set at its minimum $\bar{M}$. This regime is optimal when the rebel group's opportunity cost of conflict $\alpha$ and the government's credibility are high enough.

The repressive equilibrium regime corresponds to the situation $\theta \in[\underline{\theta}(I, \alpha) ; \bar{\theta}(I, \alpha))$ and $\alpha<1$. In such a case, the state relies both on the transfer and on military spending to deter a rebellion. This regime is optimal when the government's credibility is weak and the rebel group's opportunity cost of conflict relatively high.

The civil war regime corresponds to the case $\theta<\min \{\bar{\theta}(I, \alpha), \underline{\theta}(I, \alpha)\}$. As indicated on Fig. 1, this can occur for two reasons. When $\alpha<\Gamma(I) /\left(R+N_{G}\right)$, an incentive compatible peace allocation is not feasible. When $\alpha \geq \Gamma(I) /\left(R+N_{G}\right)$, the government prefers civil war to any feasible peace contract.

The shape of the threshold curves $\underline{\theta}(I, \alpha)$ and $\bar{\theta}(I, \alpha)$ highlights the main trade-offs involved in the choice of political regimes and the relative importance of institutions $\theta$ and opportunity cost of conflict $\alpha$. All else held constant, both $\underline{\theta}$ and $\bar{\theta}$ are decreasing functions of $\alpha$. Both better institutions and a higher opportunity cost are favorable to a peaceful solution, and to a redistributive regime rather than a repressive one. A higher opportunity cost compensates for a lower ability to commit, and reciprocally.

Specifically, when institutions $\theta$ are weak and the opportunity cost of conflict $\alpha$ is not too high, the government is not willing, or not in a position, to accommodate the challenger, and a civil war erupts. However, for higher opportunity costs, a mix of deterrence and redistribution may allow the government to implement a peaceful, though repressive, political regime, even when institutions are weak. As institutions improve, deterrence loses its bite against the promise of redistribution, and the government favors redistribution over repression. For low opportunity $\operatorname{costs} \alpha$, deterrence is dominated by the promise of transfers: whenever the government can achieve social peace, it implements the redistributive regime.

Comparative statics. Other determinants of the political regimes can also be discussed in more detail. First, one can notice that the thresholds $\underline{\theta}(I, \alpha)$ and $\bar{\theta}(I, \alpha)$ decrease with $\bar{M}$, as an increase in the minimum deterrent military capacity of the government tends to favor peace and and a redistributive regime rather than a repressive one. The thresholds also increase with $R$ : contestable rents make peace harder to achieve, and reduce the scope for a redistributive regime as a peaceful solution, in line with the evidence in Bazzi \& Blattman (2014). 


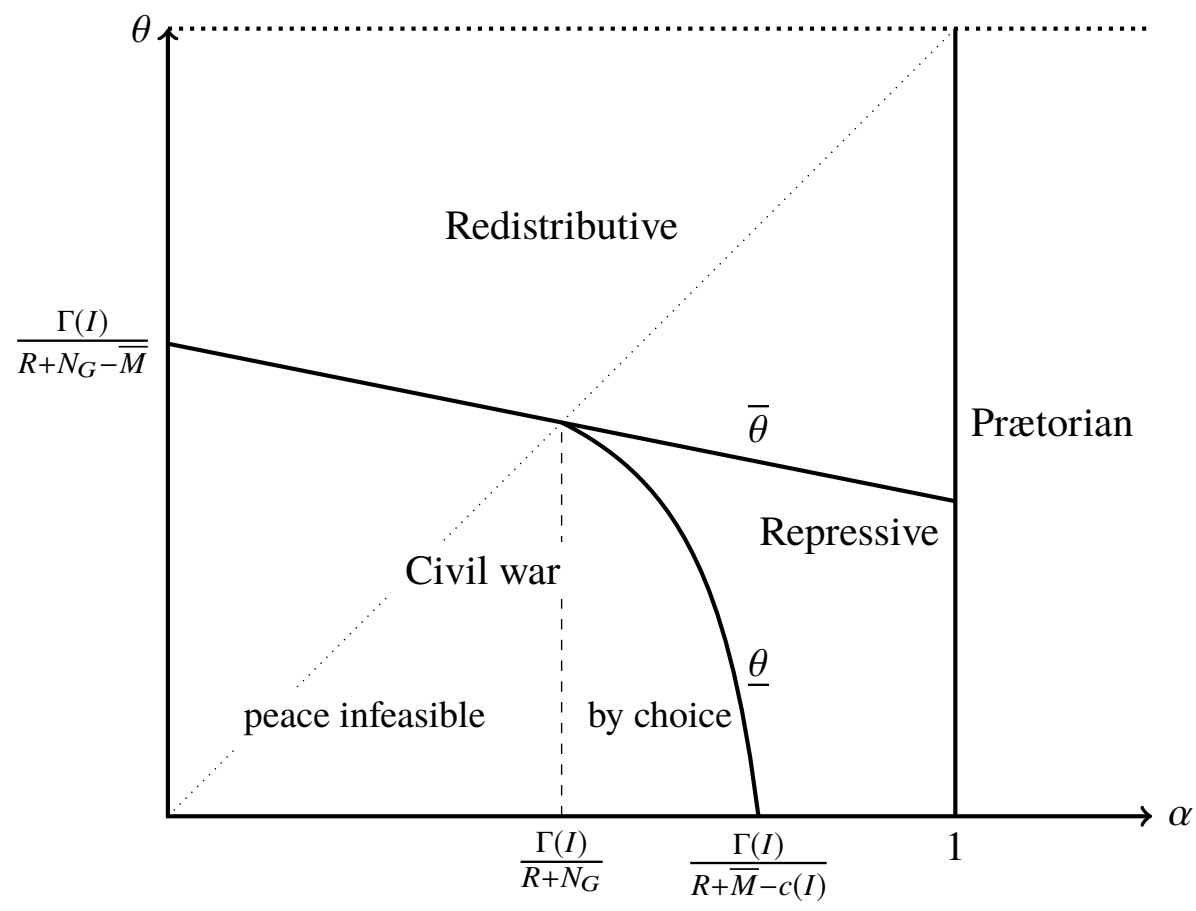

Figure 1: Typology of equilibria

Finally, both $\underline{\theta}(I, \alpha)$ and $\bar{\theta}(I, \alpha)$ are increasing with $I$, the logistics infrastructure under the control of the "merchant of war." Such an investment improves the rebel group's war technology, which makes a peaceful solution harder and more costly to implement. This feature is essential to understanding how civil wars can spill over to neighboring countries.

\section{Regional contagion of civil conflicts and the porous frontier}

In this section, we consider how "merchants of war" at porous borders are a natural source of conflict spillovers between countries that cannot fully control their territory. Taking an industrial organization perspective, our analysis highlights that a market size effect in the market for war inputs is at the heart of strategic complementarities between political regimes at a regional level. The occurrence of civil wars is then jointly determined at a regional level, depending on domestic factors in each country. Domestic factors therefore interact with the cross border diffusion mechanism, to create the possibility of multiple regional equilibria.

To get at these intuitions, we extend the framework of the previous section to two 
countries $A$ and $B$. Whenever we need to differentiate between the two countries, we add the corresponding superscript to any variable. Conversely, when referring to a generic situation, the superscript is omitted. This should leave no place for ambiguity.

\subsection{A market size effect in the market for violence}

Recall that for the case of one country in isolation where there is a conflict, the weapon broker invests in logistics infrastructure $I$ to reduce the marginal costs of supplying war inputs to the rebels. The solution $I^{i}=I^{*}\left(R^{i}\right)$ satisfies Eq. (5) for that particular country $i=A, B$.

Consider now a setting with two countries $A$ and $B$, both entering into a civil war. Now the weapons broker negotiates the quantities of war inputs to supply to each rebel group and the transfers to be made in compensation. Before entering in such negotiations, he will invest in logistics infrastructure knowing that the market for his weapon trafficking business now involves two rebel groups. He therefore chooses an investment $I^{A B}$ to maximize $\sum_{i=A, B}\left(p_{i}^{N}(I)-c(I) w_{i}^{N}(I)\right)-\phi(I)$ (where $p_{i}^{N}$ and $w_{i}^{N}$ are the price and the war input quantities negotiated with each rebel group in country $i$ ). With joint civil wars, investment $I^{A B}$ is then given by the first order condition:

$$
c^{\prime}\left(I^{A B}\right)\left(w_{A}^{N}\left(I^{A B}\right)+w_{B}^{N}\left(I^{A B}\right)\right)+2 \phi^{\prime}\left(I^{A B}\right)=0
$$

Comparing the two expressions in (5) and (6) shows that $I^{A B}>I^{A}, I^{B} .{ }^{13}$ The weapons broker faces a larger market, and therefore invests more in a cost-reducing war supply technology. This corresponds to a market size effect on the market for war inputs. The decision to go to war for one rebel group therefore depends on the other rebel group's decision to go to war.

To account for a market size effect on the market for violence, we presented the situation of a monopolistic weapon broker investing in significant logistic infrastructure to supply a bundle of war inputs to rebel groups. As pointed out by the policy literature on the topic (see the previous section), the structure of the market for war inputs is sometimes best characterized by the sales of various types of imperfectly substitutable war inputs supplied by an array of local crafting producers, warlords or communities each operating at smaller production scales. In that case, the market structure might be best captured by monopolistic competition à la Dixit-Stiglitz. In Appendix B, we propose an extension of our analysis to a model with such view of the market for violence. We show that it yields the same qualitative insights as the present mechanism: the market size effect on the market for war inputs again links the decisions to rebel at a regional level.

\footnotetext{
${ }^{13}$ Condition (4) in each country is a sufficient condition.
} 


\subsection{Regional contagion of civil conflict}

We are now in a position to discuss the issue of the regional clustering of political regimes and civil wars. To ensure that our setup allows for contagion, we suppose that the following condition holds in both countries, so that either country may be the source of the contagion:

$$
\alpha<\frac{\Gamma\left(I^{A B}\right)}{R+\bar{M}-c\left(I^{A B}\right)}
$$

To clarify, $R$ and $\bar{M}$ are country-specific. The framework is therefore adequate to examine a wealth of symmetric or asymmetric country dyads. The countries may be resource-rich (high $R$ ) or not, and they also may display different military technologies (materialized by different levels of $\bar{M}$ ). Let us introduce the following intuitive notations for each country: ${ }^{14}$

$$
\begin{cases}\underline{\theta}_{W}=\min \left[\bar{\theta}\left(I^{A B}, \alpha\right), \underline{\theta}\left(I^{A B}, \alpha\right)\right] & \bar{\theta}_{W}=\bar{\theta}\left(I^{A B}, \alpha\right) \\ \underline{\theta}_{P}=\min [\bar{\theta}(I, \alpha), \underline{\theta}(I, \alpha)] & \bar{\theta}_{P}=\bar{\theta}(I, \alpha)\end{cases}
$$

For a given country, $\underline{\theta}_{W}$ and $\bar{\theta}_{W}$ (resp. $\underline{\theta}_{P}$ and $\bar{\theta}_{P}$ ) characterize, at a value $\alpha$, the institutional thresholds for a civil war and for a redistributive regime, when the neighbor is in a civil war (resp. in peace). ${ }^{15}$ Since functions $\underline{\theta}($.$) and \bar{\theta}($.) are both decreasing in logistics infrastructure $I$, we get that $\bar{\theta}_{W}>\bar{\theta}_{P}$ and $\underline{\theta}_{W}>\underline{\theta}_{P}$. A civil war abroad raises the institutional quality necessary to implement a redistributive state, as well as the institutional quality necessary to avoid a civil war. As a consequence, a country which would have been at peace without a bad neighbor may be forced into a civil war, and a redistributive regime may be turned into a repressive one. Fig. 2 illustrates this. The full lines characterize the different regimes when no neighbor is in a civil war, and the dashed lines the regimes when a neighbor is facing a civil conflict.

The figure illustrates clearly that a bad neighbor is a source of institutional vulnerability, whether because it can force a redistributive regime into a repressive one, or because it sets the stage for a civil war. The following proposition immediately follows:

Proposition 1 1. Country $A$ is at peace while $B$ is at war if and only if $\theta^{A} \geq \underline{\theta}_{W}^{A}$ and $\theta^{B}<\underline{\theta}_{P}^{B}$ (and reciprocally).

2. Regional peace is an equilibrium when $\theta \geq \underline{\theta}_{P}$ in both countries.

\footnotetext{
${ }^{14}$ Although we omit the country indexes for notational convenience, the threshold functions $\bar{\theta}($.$) , and$ $\underline{\theta}($.$) are country specific (e.g. should be understood as \bar{\theta}^{i}($.$) and \underline{\theta}^{i}($.) . Likewise, the optimal level of investment in logistics infrastructure $I$ undertaken by the war broker in case only country $i$ is at war is country specific (e.g. should be understood as $I=I^{i}$ ).

${ }^{15}$ Notice that if $\alpha \leq \Gamma\left(I^{A B}\right) /\left(R+N_{G}\right)$, then $\underline{\theta}_{W}=\bar{\theta}_{W}$, and if $\alpha \leq \Gamma(I) /\left(R+N_{G}\right)$, then $\underline{\theta}_{P}=\bar{\theta}_{P}$.
} 


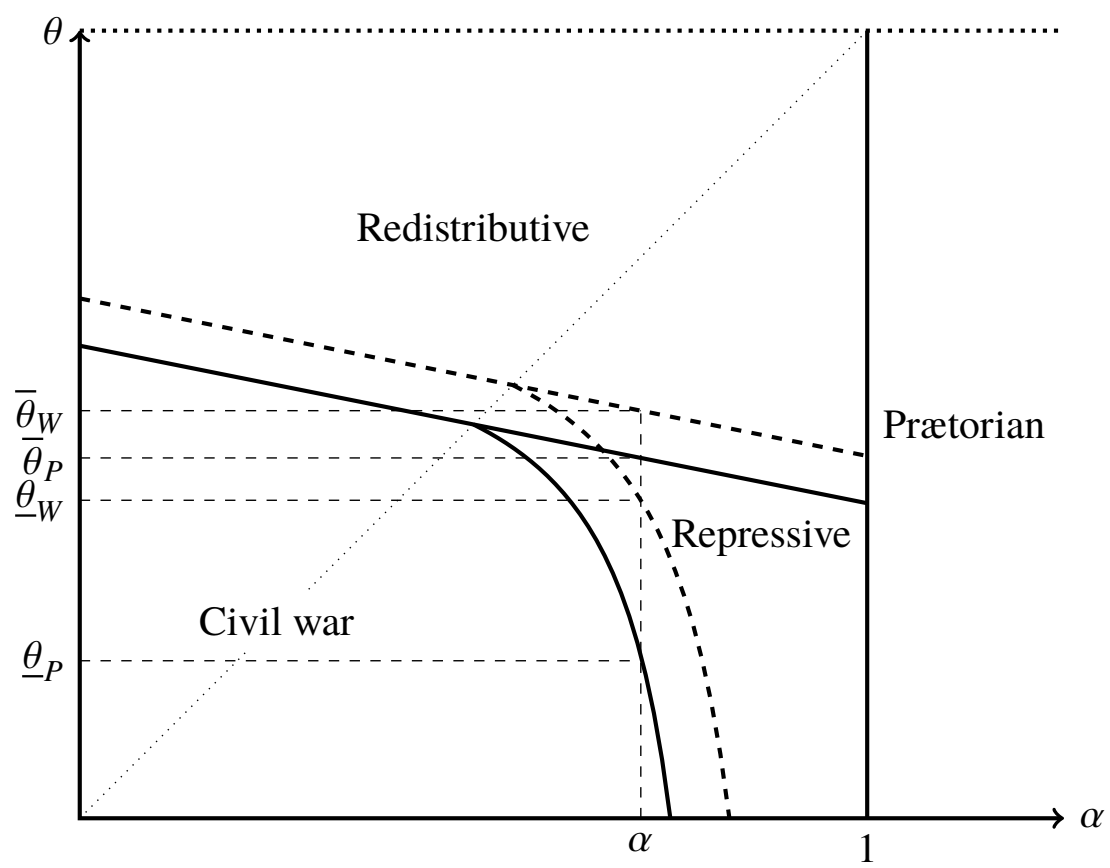

Figure 2: Contagion due to size effect in the war market. Full line: without spillovers, Dashed line: with spillovers.

3. Regional conflict is an equilibrium when $\theta<\underline{\theta}_{W}$ in both countries.

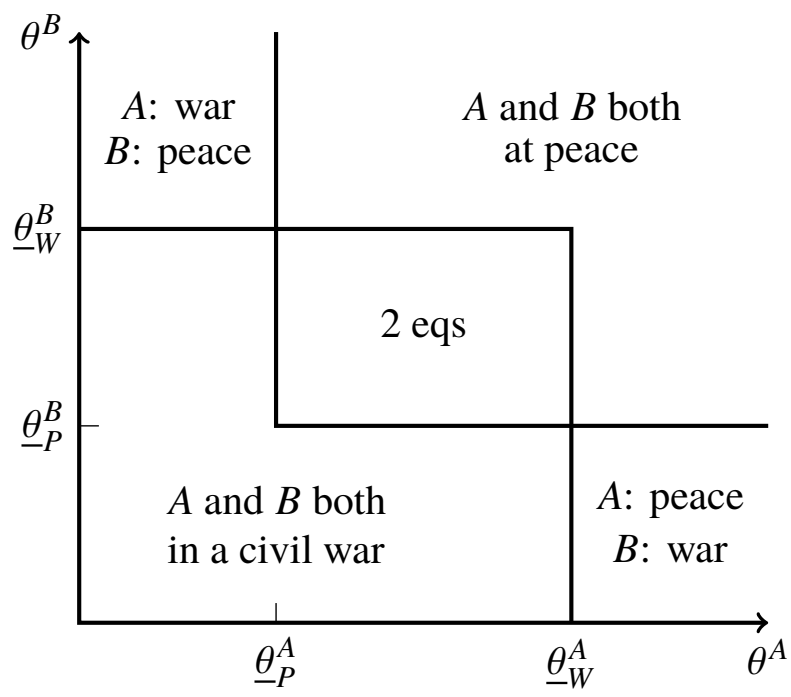

Figure 3: Regional equilibria with spillovers 
Fig. 3 illustrates the proposition. For a rebel group, a neighboring rebellion means cheaper access to war inputs, and better odds in the case of a civil war. As a result, civil war in a country can diffuse to the whole region. A country with weak enough institutions cannot escape a civil war, regardless of what happens in neighboring countries. Conversely, strong enough institutions immunize a country against contagion. Civil war and peace may only coexist in a single region when countries differ widely in terms of their institutions (item 1 of the proposition).

When countries have comparable levels of institutions, clusters of conflict and peace are likely to appear. The two countries are either both at peace (item 2) or both in a civil war (item 3). The negative spillovers of a neighboring civil war are felt at intermediate levels of institutional development, ie. when a country is such that $\underline{\theta}_{P} \leq \theta<\underline{\theta}_{W}$. A country in that range is vulnerable, and can be destabilized by a neighboring conflict. As a matter of fact, in that region, the return for a given country to implementing a peaceful regime depends positively on the neighboring country also implementing a peaceful regime. Policy regimes across countries are strategic complements. With a peaceful neighbor, the country will manage to remain at peace, while with a neighbor subjected to a civil conflict, the country will also face a civil conflict. The market size effect on the market for violence creates a cross border spillover and a strategic complementarity between the political choices of regimes across governments. As a consequence, for the same observable regional fundamentals, multiple policy regimes may arise. While the model cannot account for which regional equilibrium might emerge, it does account for the pattern of civil war clustering.

Interestingly, in the situation in which there are multiple equilibria, which regional equilibrium emerges depends on which kind of expectations countries have about the region's institutional stability. The strategic complementarities between neighboring governments in their choice of political regimes make the institutional stability of a region highly sensitive to small extrinsic factors which are not directly related to observable economic fundamentals. Under pessimistic expectations about each other's ability to implement a peaceful regime within their national territory, both governments may be ready to accept a civil war domestically. Conversely, under optimistic expectations about the institutional stability of the region, each country may indeed be able to avoid a civil conflict. These elements suggest some considerations for policy. First, it might be difficult to predict the regime which a country might end up with. Second, a specific regional situation at a given point in time may be fragile to shifts in expectations by the different regional agents and may lead quickly to a very different political configuration through diffusion effects. Third, the international exchange of information and communication at the governmental level can be useful to coordinate expectations on the peaceful regional equilibrium. A government's optimism about the other country's domestic peace is not sufficient: it must convince the other government to be optimistic as well. 
Note that the previous discussion focuses on the main issue of civil war vs. peace, but the argument can be extended to the regional connections to other peaceful political regimes as well. In particular, a government that, alone, would have implemented a redistributive regime, may be forced into a repressive state as a result of a neighboring civil war.

Comparative statics. Our model emphasizes internal factors and the diffusion channel as complementary sources of local civil conflict. Economic shocks in one country may therefore have repercussions for the region's stability. For instance, consider a country whose institutions are good enough to immunize it against contagion. An increase in the price of the contestable resource (which increases the value $R$ ) could possibly take that country's immunity away, making it vulnerable to contagion. Before the price shock, the only regional equilibrium is peace (item 2 of the proposition), even with vulnerable neighbors. Absent any vulnerable neighbors, domestic fundamentals may still allow the country to absorb the price shock. However, with a vulnerable neighbor, the diffusion channel opens up the possibility of a regional equilibrium of civil wars.

The diffusion channel also interacts with other internal factors of conflict such as the government's military advantage (captured by our parameter $\bar{M}$ ). When a government loses some of its military advantage, even though this would not be enough to destabilize the country in the absence of vulnerable neighbors, again it may create a regional complex of civil wars because of the interaction with the diffusion channel.

\section{Institution building and cross-border contagion}

So far, each country's institutions $\theta$ were considered exogenous. In this section we investigate the incentives for governments to invest in better institutions. This extension highlights new implications of regional contagion mechanisms not only at the level of policy regimes, but also at the level of institutional structures across countries.

\subsection{A simple model of institution building}

Let us return to the simple framework of section 3 and consider now that the government can invest in institutions. We simplify the discussion by assuming constant marginal costs $s$ of investing in $\theta .{ }^{16}$ Consider first the case of a country in isolation. Thanks to Prop. 4, we can write the indirect payoffs to the government:

\footnotetext{
${ }^{16}$ We could have alternatively assumed an increasing convex cost function $S$ with $S(0)=S^{\prime}(0)=0$. It is easy to see that for some parameter values, one may obtain the possibility of an optimal interior level of institutions $\theta^{*}(I, \alpha)$ strictly below the threshold $\bar{\theta}(I, \alpha)$. Nevertheless the solution still features the property that for $\alpha$ below a threshold, it is optimal for the state not to invest in institutions and to pick the corner solution $\theta=0$.
} 


$$
V(\theta)= \begin{cases}N_{G}-\bar{M}+c(I) & \text { when } \theta<\underline{\theta}(I, \alpha), \\ \frac{1-\theta}{\alpha-\theta}\left(\alpha\left(N_{G}+R\right)-\Gamma(I)\right) & \text { when } \underline{\theta}(I, \alpha) \leq \theta<\bar{\theta}(I, \alpha) \text { and } \\ N_{G}+R-\Gamma(I)-(1-\alpha) \bar{M} & \text { when } \bar{\theta}(I, \alpha) \leq \theta .\end{cases}
$$
as: ${ }^{17}$

The government then sets $\theta_{\text {opt }}$ so as to maximize $V(\theta)-s \theta$, which can be characterized

Lemma 1 For a given logistics infrastructure I, define

$$
\underline{\alpha}(I)=\frac{s \Gamma(I)-(R-\Gamma(I)-c(I))\left(R+N_{G}-\bar{M}\right)}{\bar{M}\left(R+N_{G}-\bar{M}+s\right)} .
$$

Then, the optimal investment in institutions is

$$
\theta_{\text {opt }}= \begin{cases}\bar{\theta}(I, \alpha)=\frac{\Gamma(I)-\alpha \bar{M}}{R+N_{G}-\bar{M}} & \text { if } \alpha \geq \underline{\alpha}(I) \\ 0 & \text { otherwise. }\end{cases}
$$

This lemma states that the government does not invest in institutions if the opportunity cost of conflict is low. In that case, the propensity of that challenging group to enter into conflict is too high for the government to contain it at a reasonable cost. Civil war becomes inevitable, or preferable for the government, and institutions are useless in a civil war. Conversely, if the opportunity cost of conflict is high enough, then it is profitable for the government to invest in institutions. Again, the parameters may all be country specific, which would be accounted for by the appropriate superscripts.

Conditional on investing in institutions, the government sets $\theta_{o p t}=\bar{\theta}(I, \alpha)$ : this is the minimum level of commitment that allows the implementation of a redistributive regime. Interestingly, investment in institutions is non-monotonic in $\alpha$. The intuition for this is as follows: for low enough levels, the rebels have little to lose, and government finds it too costly to invest enough in institutions to avoid a civil war. Conversely, above a certain threshold, the government prefers to invest in institutions so as to achieve a peaceful outcome. However, as the opportunity cost of conflict further rises, the challenger is likely to accept a lower level of commitment from the government. This is illustrated in Fig. 4.

Endogenous investment in institutions does not affect our intuitions relative to the role of investment $I$ in logistics infrastructure in the regional spillover mechanism. As a

\footnotetext{
${ }^{17}$ The proof is straightforward: first notice that in a repressive regime, $V$ is increasing and convex in $\theta$. We need only compare the corner payoffs of the government at $\theta=0$ and $\theta=\bar{\theta}(I, \alpha)$ or $V(0)=N_{G}-\bar{M}+c(I)$ to $V(\bar{\theta}(\alpha))=N_{G}+R-\Gamma(I)-(1-\alpha) \bar{M}-s \bar{\theta}(\alpha)$. Therefore investment occurs at $\theta=\bar{\theta}(\alpha)$ iff $\alpha \bar{M} \geq s \bar{\theta}(\alpha)+$ $\Gamma(I)+c(I)-R$ which is equivalent to the condition expressed in the Lemma.
} 


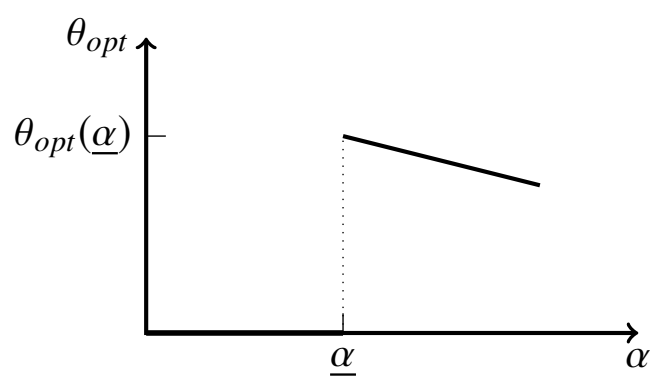

Figure 4: Investment in institutions

matter of fact, it is easy to see that $\underline{\alpha}(I)$ is an increasing function of $I$ when the resource rents $R$ are large enough. ${ }^{18}$ Likewise, simple observation shows that $\alpha$ is increasing in the marginal cost $s$ of institutions: a challenger becomes increasingly hard to accommodate as the cost of institutions increases.

\subsection{Regional institutional quality clusters}

It is now time to reintroduce the two-country setup, and to extend it to account for regional patterns of institution building. Remember that having a bad neighbor generates a market size effect on the market for violence, raising investment in logistics infrastructure by the war broker from $I$ to $I^{A B}$. The previous discussion immediately yields the following proposition:

Proposition 21 . When $\alpha \geq \underline{\alpha}\left(I^{A B}\right)$, the government avoids a contagion from a civil war abroad by investing in better institutions.

2. When $\underline{\alpha}(I) \leq \alpha<\underline{\alpha}\left(I^{A B}\right)$, the country would not be able to avoid contagion from a civil war abroad. When the condition holds for the two countries in a regional complex, they are either both at peace or both in a civil war.

3. When $\alpha<\underline{\alpha}(I)$, the country is in a civil war regardless of its neighbor.

In the previous sections, we examined contagion in the absence of any institutional response from the government. With the possibility of investing in better institutions, the state is able to withstand a larger shock on the opportunity cost of conflict. Fig. 5 highlights the equilibrium pattern of institution building at the regional level, depending on the structure of the opportunity cost of conflicts across countries.

Comparative statics. When the opportunity costs of conflict are very asymmetric within a region, a civil war may erupt in country $A$, but country $B$ may still be in a

\footnotetext{
${ }^{18} \mathrm{~A}$ sufficient condition, independent from the marginal cost $s$, is that $\Gamma(I)+c(I)$ be increasing in $I$, ie. $\left(1-\pi_{0}\right) R>e^{2} c(0)$.
} 


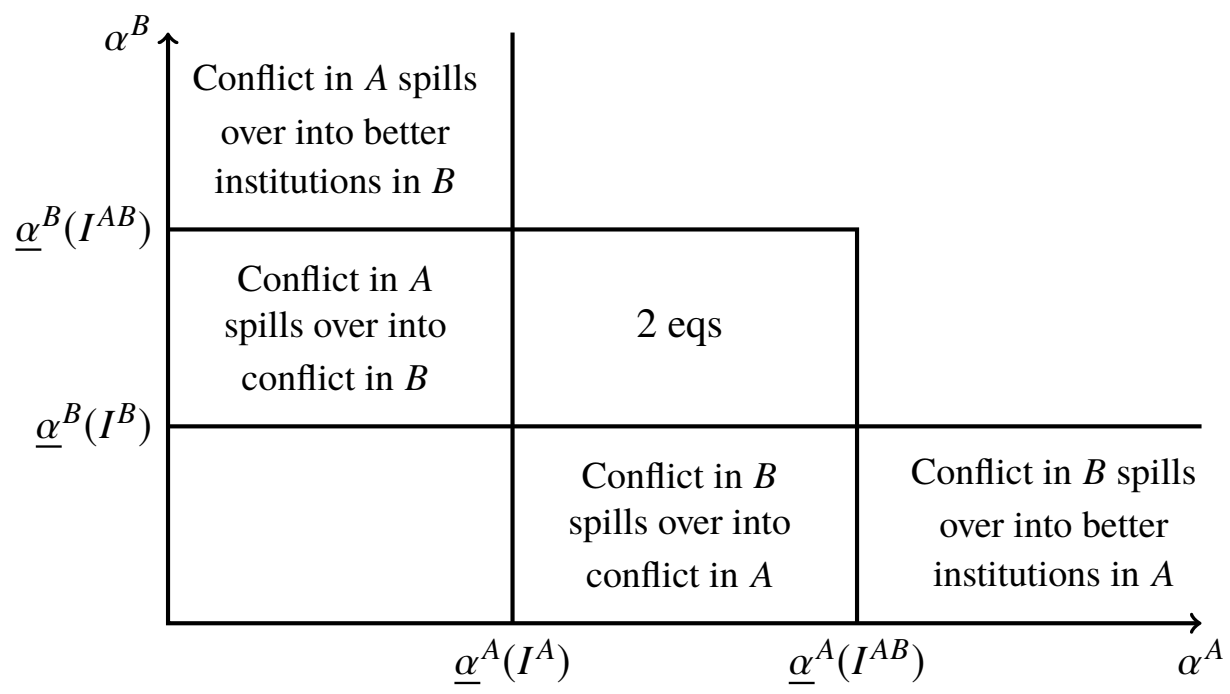

Figure 5: The spillovers of conflict and regional patterns of institutions

position to avoid contagion (and reciprocally). As long at the civil conflict in $A$ does not discourage the government of $B$ from implementing a peaceful regime, this may actually lead to improved institutions in this country. This situation may exist when country $B$ has an inherently high level of stability or because of small spillovers from the civil war in country $A$. Since in that case country $B$ is not a source of instability for country $A$, the latter is in a civil war only if it is inherently unstable. Interestingly in such a case, strong regional asymmetries in the opportunity cost of the various challengers lead to even stronger asymmetries in institutions. Indeed, the risk of contagion from a weak unstable neighbor translates into stronger incentives to invest in good institutions for a country which is already resilient to internal conflicts (item 1 of the proposition). From this, we may expect that countries at the frontier of regional clusters of civil conflict should be characterized by better, rather than worse, institutions.

When the asymmetries are less pronounced, the model not only predicts regional clusters of civil wars, but also clusters of institutional quality. Except if country $B$ is inherently very stable and spillovers are not too large, its government may prefer to allow a neighboring civil war to spread, instead of investing into institutions. A civil war in $A$ would then spill over into a civil war in $B$, and both countries would end up with failed institutions (and reciprocally).

For intermediate levels of $\alpha$ in both countries, the spatial correlation is quite clear. Both countries may be at peace and both invest in institutions, or they may be both at war and not invest at all. Once again, the model does not predict which specific equilibrium emerges, it only predicts that the contagion of civil wars results in regional clusters of institutional quality (item 2 of the proposition). 
Finally, for low levels of $\alpha$, a country is in a civil war regardless of what happens in the region. This may generate spillovers regionally through two possible mechanisms. On the negative side, it may trigger a civil war for a vulnerable neighbor. Interestingly on the positive side, it may also induce better institutional building for more resilient neighbors that do not become involved in civil conflicts (item 1 of the proposition).

\section{Policy implications}

Given the regional externalities associated with civil war contagion effects, it is natural to expect gains from external intervention and regional cooperation mechanisms. This feature has been widely recognized in the international relations literature. Regan (2002) counts that about two thirds (97 out 150) of all civil wars over the period 1945-97 were accompanied by interventions from foreign countries or international organizations. Several studies point out the fact that the risk of the transnational spread of a civil war can make states with strong interests in a region intervene to contain the conflict (Salehyan \& Gleditsch, 2006; Gleditsch, 2007, 2009; Kathman, 2011).

Our framework allows us to account for such policy interventions and to highlight some of their implications. A natural step in that direction is to identify the incentives for a given country to implement such a policy. For this, we consider the benefits for a given country to have a peaceful regional neighborhood.

\subsection{The benefits of a good neighbor}

Taking into account the fact that the state may or may not invest into institutions, the government's indirect payoff when it has a good neighbor (Peace) can be written:

$$
V_{P}(\alpha)=\left\{\begin{array}{lr}
N_{G}-\bar{M}+c(I) & \text { when } \alpha<\underline{\alpha}(I) \\
N_{G}-\bar{M}+R-\Gamma(I)-s \frac{\Gamma(I)}{R+N_{G}-\bar{M}}+\alpha \Delta \cdot \bar{M} & \text { when } \alpha \geq \underline{\alpha}(I)
\end{array}\right.
$$

with $\Delta=\left(R+N_{G}-\bar{M}+s\right) /\left(R+N_{G}-\bar{M}\right)$. Note that $\Delta \cdot \bar{M}$ is the marginal gain from institutions building when the opportunity cost of conflict $\alpha$ increases. Similarly, when the country has a bad neighbor (War), the government's indirect payoff can be written:

$$
V_{W}(\alpha)= \begin{cases}N_{G}-\bar{M}+c\left(I^{A B}\right) & \text { when } \alpha<\underline{\alpha}\left(I^{A B}\right) \\ N_{G}-\bar{M}+R-\Gamma\left(I^{A B}\right)-s \frac{\Gamma\left(I^{A B}\right)}{R+N_{G}-\bar{M}}+\alpha \Delta \cdot \bar{M} & \text { when } \alpha \geq \underline{\alpha}\left(I^{A B}\right)\end{cases}
$$

These payoffs are plotted in Fig. 6. We also represent the difference between the two, which accounts for the benefits to the government to have a good neighbor. $v_{1}=$ 
$c(I)-c\left(I^{A B}\right)$ captures the extent of the spillover associated with a neighboring civil war in the presence of a porous frontier. Conversely $v_{2}=\Delta \cdot\left(\Gamma\left(I^{A B}\right)-\Gamma(I)\right)$ denotes the additional cost of peace when the government is in a position to avoid contagion from the bad neighbor. In the case of a civil war, the government needs to compensate its challenger who would benefit from a larger and more efficient market for violence triggered by war borker's investment in logistics infrastructure at the porous frontier.

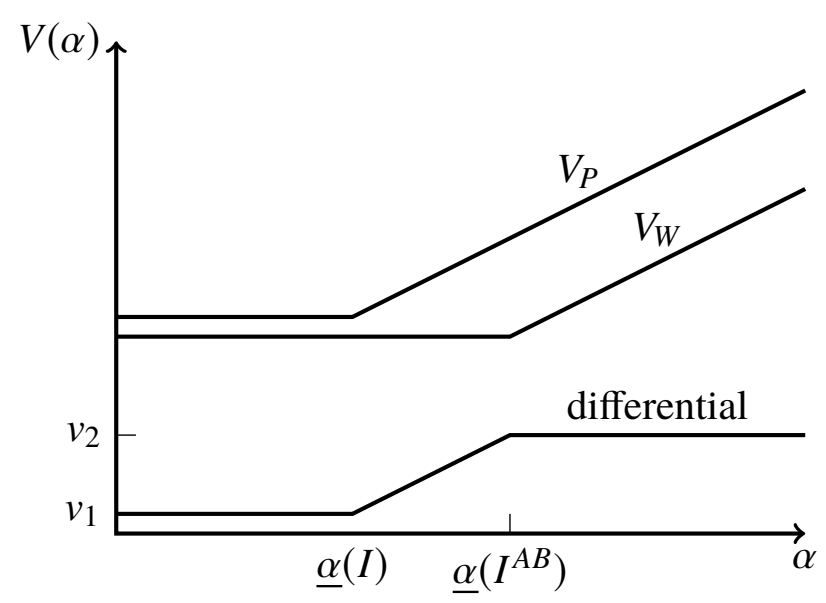

Figure 6: The government's indirect payoffs

A government clearly benefits from not having bad neighbors, as illustrated by the differential shown on Fig. 6. It may thus consider the option of directly affecting the policy regime of its neighbors. A country $A$ may then undertake an intervention in country $B$, to avoid a civil war there, which would spill over into $A$. Our previous analysis suggests two natural channels to avoid a civil war in country $B$. The government in country $A$ may raise the opportunity cost of conflict for the challenger in country $B$, or may lower the threshold $\underline{\alpha}^{B}$ above which the government of $B$ ensures peace by investing in institutions.

\subsection{Military intervention}

The government in country $A$ may wish to discourage a rebellion in country $B$. To that end, let us assume that $A$ 's government can raise $\alpha^{B}$. The cost of raising it by an increment $\epsilon$ is written $C_{2}^{A}(\epsilon)$, where $C_{2}^{A}$ is an increasing function. It makes sense to pay for $\alpha^{B}$ only insofar as it ensures that $B$ is at peace. When there are multiple regional equilibria that depend on self-confirming expectations, which regional equilibrium policy regime arises becomes an issue. As a simplified heuristic, let us assume that the government in country $A$ believes that the peaceful equilibrium prevails with probability $\psi$, whenever 
multiple regional policy equilibria exist. The following proposition provides a formal solution, which we discuss below:

Proposition 3 1. When $\alpha^{A} \geq \underline{\alpha}^{A}\left(I^{A B}\right)$, A's government prevents a conflict in country $B$ if $v_{2} \geq C_{2}^{A}\left(\underline{\alpha}^{B}\left(I^{B}\right)-\alpha^{B}\right)$.

2. When $\underline{\alpha}^{A}\left(I^{A}\right) \leq \alpha^{A}<\underline{\alpha}^{A}\left(I^{A B}\right)$, A's government increases the opportunity cost of conflict in $B$ up to $\underline{\alpha}^{B}\left(I^{B}\right)$ if $\psi\left(v_{1}+\Delta \bar{M}\left(\alpha^{A}-\underline{\alpha}\left(I^{A}\right)\right)\right) \geq C_{2}^{A}\left(\underline{\alpha}\left(I^{B}\right)-\alpha^{B}\right)$, and even further up to $\underline{\alpha}\left(I^{A B}\right)$ if $v_{1}+\Delta \bar{M}\left(\alpha^{A}-\underline{\alpha}\left(I^{A}\right)\right) \geq C_{2}^{A}\left(\underline{\alpha}\left(I^{A B}\right)-\alpha^{B}\right)$.

3. When $\alpha^{A}<\underline{\alpha}^{A}\left(I^{A}\right)$, A's government prevents a conflict in country $B$ if $v_{1} \geq$ $C_{2}^{A}\left(\underline{\alpha}^{B}\left(I^{A B}\right)-\alpha^{B}\right)$

When $\alpha^{A}$ is high enough, country $A$ is immune to contagion from a bad neighbor $B$. Still, $A$ 's government would need to improve the quality of institutions to avoid such an outcome, at a cost. If a rebellion looming in country $B$ can easily be bought off, it might be less costly to avoid a civil war there than to invest in better institutions at home (item 1 of the proposition).

For intermediate values of $\alpha^{A}$, there are multiple regional policy equilibria. In such a case $A$ 's intervention in $B$ depends on its priors $\psi$ to obtain a peaceful regional regime. An optimistic enough government cares only about making a peaceful equilibrium possible, since it believes that whenever it is possible, this happens with a high enough probability. As a result, $A$ 's optimistic government intervenes in $B$ only to make sure that $\alpha^{B}$ is raised up to $\underline{\alpha}\left(I^{B}\right)$. Indeed in such a case, country $A$ will intervene as long as the cost of the intervention $C_{2}^{A}\left(\underline{\alpha}\left(I^{B}\right)-\alpha^{B}\right)$ is less than the sum of the expected utility gain from staying at peace $\psi \cdot v_{1}$ and the expected gain from investing in redistributive institutions $\psi \cdot \Delta \bar{M}\left(\alpha^{A}-\underline{\alpha}\left(I^{A}\right)\right)$ (item 2 of the proposition).

Conversely, a government with a low prior $\psi$ intervenes only to make sure that a bad equilibrium cannot happen in the region. As a result, $A$ 's pessimistic government intervenes in country $B$ when the intervention brings $\alpha^{B}$ above the threshold $\underline{\alpha}^{B}\left(I^{A B}\right)$ which makes the bad equilibrium impossible, implying that it is less likely to intervene than an optimistic government (as $\underline{\alpha}^{B}\left(I^{A B}\right)>\underline{\alpha}\left(I^{B}\right)$ ). Indeed, the cost of foreign intervention will now be equal to $C_{2}^{\bar{A}}\left(\underline{\alpha}\left(I^{A B}\right)-\alpha^{\bar{B}}\right)$ while the benefits for sure will be the sum of the gain from staying at peace $v_{1}$ plus the gain from investing into redistributive institutions $\Delta \bar{M}\left(\alpha^{A}-\underline{\alpha}\left(I^{A}\right)\right)$.

Finally, when $\alpha^{A}$ is low enough, country $A$ is in a civil war (except if $B$ 's government intervenes). It still suffers a (small) loss from a bad neighbor, due to the market size effect in the market for violence. It might therefore intervene to stabilize its neighbor as one facet of its strategy to address its own rebellion. This will occur however only if foreign intervention is easy enough to undertake (e. g such that $\left.C_{2}^{A}\left(\underline{\alpha}^{B}\left(I^{A B}\right)-\alpha^{B}\right) \leq v_{1}\right)$.

A number of features are worth mentioning. First, proposition 3 is based on the premise that $A$ 's government can intervene in $B$, and can increase the opportunity cost 
of conflict there. This is in line with Kathman (2010) who considers the possibility of military intervention in another country, so as to quell a rebellion. ${ }^{19}$

The intermediate case (item 2 of the proposition) also indicates that the extent of foreign policy intervention may depend on factors extending beyond the standard socioeconomic characteristics of the targeted country and the external intervening country. Indeed, the nature of the beliefs and doctrines on the range of plausible international outcomes that an intervening outside government has may matter for the decision to intervene and the scale of this intervention. Interestingly, the current literature on motivations to intervene focuses on a number of well defined characteristics, such as third parties' security interests (i.e. proximity to conflict), humanitarian concerns (i.e. casualties and refugees), ethnic and colonial ties to a conflict, or economic factors (rents and the presence of natural resources). ${ }^{20}$ Our analysis suggests that beyond such socio-economic characteristics, there are contexts in which other more subjective and immaterial dimensions such as worldviews, doctrines, and expectations, may also be important to explain patterns of external interventions.

Finally, note that in our set-up, direct military intervention in country $B$ changes the rebel group's opportunity cost of conflict $\alpha^{B}$. Since we have defined $\alpha^{B}=a^{B} / \gamma^{B}$, this would correspond to a decrease in $\gamma^{B}$, the challenger's absolute advantage in the conflict technology. The model also suggests that an alternative to military intervention might be to act upon $a^{B}$, in other words to improve the economic terms of trade of the challenger group in country $B$. Our model suggests therefore that economic aid policies favoring structural market access and economic opportunities for the rebel group may, to some extent, be substitutes to direct military intervention. ${ }^{21}$

\subsection{Improving the neighborhood and the role of regional agreements}

Quelling a rebellion in a neighboring country might involve substantial costs. There are other policy options, some of which may sometimes be more expedient. Let us now assume that instead of raising $\alpha^{B}, A$ 's government has the option of lowering $\alpha^{B}$. To that end, $A$ 's government may increase the military advantage of $B$ 's government, or reduce the likelihood of success for a rebellion, arguably through other forms of military cooperation or promises to support a struggling neighbor. It could also increase country $B$ 's public resources by providing budget support in the form of international aid.

$A$ 's government also has the option of favoring the emergence of good institutions in $B$, by facilitating investment in institutions (e.g. by reducing in the model the cost $s^{B}$ of institutional investment in $\theta^{B}$ ). There are several ways to do this. Bilateral cooperation between country $B$ and an external development institution such as the

\footnotetext{
${ }^{19}$ In Kathman (2011), the argument is extended to the regional level.

${ }^{20}$ See for instance Regan (1998, 2000); Findley \& Teo (2006); Koga (2011); Bove et al. (2016).

${ }^{21}$ This idea was at the heart of USAID's Alternative Development policy in Colombia. See Vargas Meza (2011).
} 
World Bank may lower the costs of investing in institutions. A regional agreement structure including country $B$ may also help the government of this country commit to a peaceful social contract by increasing the costs of violating this contract. So-called international "audience costs" arise from the conditionality imposed by the regional agreement organization on its members. In such case, any reversal of a domestic redistributive policy regime may directly bring sanctions or exclusion from the benefits associated to the agreement membership. The agreement's structure may also provide an external monitoring capacity that increases the transparency of a member country's institutional governance. Diffusion of information and increased exposure may again help country $B$ 's government to commit to domestic redistributive policies. ${ }^{22}$

Through the audience costs and the peer pressure effects it generates, it should be noted that even a regional agreement structure with a weak enforcement capacity may be useful to enhance a country's institutions. An example is the African Peer Review Mechanism (APRM) associated to the African Union (AU). ${ }^{23}$ Member countries of the AU can voluntarily adhere to the APRM, as a self-monitoring mechanism supervised by an independent panel consisting of 7 eminent experts of "high moral stature and demonstrated commitment to the ideals of Pan Africanism". Adhering countries have to produce a self-assessment on various governance and socio-economic development dimensions and to issue a draft Programme of Action together with the participation of all domestic stakeholders (trade unions, women, youth, civil society, private sector, rural communities and professional associations). An ensuing report, together with the Programme of Action compiled by the Government, is then published formally. Eventually, this report is interpreted by external donors as a signaling device.

Formally, Prop. 3 suggests that the effectiveness of an external intervention to stabilize country $B$ depends on narrowing the gap $\underline{\alpha}-\alpha^{B}$. This accounts therefore either for the effect of direct military intervention (e.g. increasing $\alpha^{B}$ ), or for the effect of institutional cooperation (e.g. reducing the threshold $\underline{\alpha}^{B}$ ). Note that this new interpretation also clarifies the position of $B$ 's government with respect to $A$ 's intervention. A peacebuilding intervention by country $A$ in neighboring country $B$ is warranted just to the point at which $B$ 's government is indifferent between civil conflict and no conflict. As a result, this government can always be marginally induced to cooperate with the intervention.

\subsection{Some illustrative cases}

We close this section with a discussion of specific cases that illustrate our framework and policy implications.

\footnotetext{
${ }^{22}$ The use of a regional agreement as an external commitment device for the implementation of a domestic policy has also been emphasized by Maggi \& Rodriguez-Clare (1998) in the case of trade policy.

${ }^{23}$ See details at http://aprm-au.org/
} 


\section{- Third-party military intervention and international cooperation against AQIM}

At a higher scale, regional clusters of civil wars pose another sort of threat. Arguably, there are increasing returns to scale for terrorist groups and organizations to maintain vast, persistent conflict zones. Larger uncontrolled territory means access to more diversified resources, deeper pools of potential followers, and easier logistics. Recently, several cases have highlighted how the spread of conflict is a major issue for the international community.

The terrorist group al-Qaeda in the Islamist Maghreb (AQIM) was founded in 1998 (initially under the name "Groupe Salafiste pour la Prédication et le Combat," GSPC) to contest the legitimacy of the Algerian government. However, their reach soon extended beyond the borders of Algeria: they have far-reaching regional ties, throughout the Sahelian-Saharan zone in Africa, from Mauritania to the Shabaabs in Ethiopia, and as far as Afghanistan and Iraq. Associated with frequent abductions of Western tourists and aid workers, whom they exchange for hefty ransoms, as well as with extensive weapon and drug trafficking, AQIM has been an important diffusion vector of civil conflicts in the Sahel.

In line with the discussion of the previous section, cooperation between neighboring states to attempt stabilizing the region has taken multiple forms. The African Union adopted the Convention on the prevention and fight against terrorism in 2004. The West African Economic and Monetary Union (WAEMU) and the Economic Community of West African States (ECOWAS) established institutions in charge of fighting the financing of terrorism. ${ }^{24}$ There have also been attempts at coordinating regional intelligence agencies to fight AQIM more effectively. Nevertheless, such regional cooperation remains limited, and the governments of the region do not have the military resources to intervene in neighboring countries.

To tackle these issues, the international community has been involved alongside the governments in the region to fight AQIM. Our framework suggests different policy options: a) direct military support to an incumbent government and a decrease in the absolute advantage of the challenger, b) increasing indirectly the military capabilities of the incumbent government, c) building more credible institutions of redistribution. Interestingly, the involvement of the international community follows these three lines. In the notations of the model, hotbeds of civil conflict are characterized by the superscript $B$, and are located in the Sahelian-Saharan band. Countries North and South of the band can be denoted by the superscript $A$. Civil conflict into $B$ might spill over into $A$, with global consequences.

${ }^{24}$ The WAEMU passed in 2003 the Uniform Law on the Fight Against Money Laundering in Member States of the WAEMU. The ECOWAS established the Inter-Governmental Action Group against Money Laundering in West Africa (GIABA) whose main focus is to strengthen the capacity of member states towards the prevention and control of money laundering and terrorist financing in the region. See http://www.giaba.org/ 
France's intervention illustrates the first policy option. It sent troops to fight AQIM in Mali in the high-profile 2012 Serval and 2014 Barkhane military operations. ${ }^{25}$ Incumbent regimes in that region, for all their specific problems, have counted France as an ally since independence. This military intervention demonstrates that a rebellion there had to count not only on the state's expenditure on military forces, but also on France's direct support for that state. This raised insurgent group's opportunity cost of conflict $\alpha$ (through a reduction of $\gamma$ in the conflict technology).

While France acted at the root of terrorism, the United States preferred a containment strategy. They founded the Pan-Sahel initiative in 2002, replaced in 2006 by the TransSaharan Counter-terrorism initiative to train regional military forces. ${ }^{26}$ Similarly, the United Nations Development Programme (UNDP) set up with the government of Mali the Governance, Peace and Security Programme to train local communities to take charge of their own security. ${ }^{27}$ The EU developed the Common Security and Defence Policy (CSDP), which also contributed to training regional forces. None of these countries and organizations was ready to send fighting troops in the region, but their action has contributed to supporting the military capabilities $\bar{M}$ of the local countries.

Finally, the European Development Fund (EDF) of the European Union ${ }^{28}$ is an example of the last intervention option. Indeed the Fund explicitly pursues cohesion, peace, security and stability in the region, and supports reforms aimed at decentralizing and reforming the state. One may then interpret this type of action as lowering the cost $s$ of institution building in the region.

To summarize, the fight against AQIM, in which several prominent international actors are involved, illustrates three policy options for the international community. France has offered military support to governments under attack. The United States, the UNDP and the CSDP have preferred strengthening the military forces of fragile neighbors. The EDF has supported investment in good institutions in the region.

\section{- The Arab Spring and institutional spillovers: the case of Morocco.}

The spread of the Arab Spring across Northern Africa and the Middle East generated much instability in the region. Beginning with the events of the Tunisian uprising in December 2010, it proliferated, leading to similar revolts later, in Egypt, Libya, Yemen, Syria, Bahrain, and other Arab nations (Joffé, 2011; Dalacoura, 2012). In Syria, the civil war which erupted in March 2011 favored the emergence of Jihadi militant groups, such as the Islamic State of Iraq and the Levant (ISIL), also known as ISIS or Daesh.

\footnotetext{
${ }^{25} \mathrm{See} \quad$ https://theglobalobservatory.org/2014/09/operation-barkhane-force-political-games-sahelsahara/

${ }^{26}$ See for details: https://www.globalsecurity.org/military/ops/tscti.htm

${ }^{27}$ See Sougane et al. (2015).

${ }^{28} \mathrm{See} \quad$ https://ec.europa.eu/europeaid/funding/funding-instruments-programming/fundinginstruments/european-development-fund_en
} 
As of mid-2015, they were claiming political control over a region which spanned half of Syria and a significant part of Iraq.

At the other end of the region, Morocco stands out as a rare example of relative immunity to the spread of the Arab Spring. Civil unrest did occur, on February 20th 2011. However, when it did, King Mohammed VI agreed to a constitutional reform to avoid outright riots, and did not have to request foreign military assistance or institutional support. The model predicts that when the regional spillovers on the opportunity cost of conflict are limited, in order to avoid contagion domestically, a state has to invest in $\theta$, the credibility of the revenue-sharing agreement. Indeed, the 2011 constitutional reforms in Morocco somehow illustrates this mechanism. The reforms were mainly concerned with transfers of power as well as symbolic and substantial gestures towards minorities. First, the King renounced several key discretionary powers in favor of Parliament. For instance, the Prime Minister must now be named from within the largest party in Parliament, and presides over the executive branch of government. The judiciary system is independent from the two other branches of government. Secondly, the reforms have granted new rights to women. They recognize Berber as an official language, and protect Hassaniya Arabic as a national cultural heritage. As a result, the constitutional referendum of 2011 proved successful, as $70 \%$ of the population voted and $98 \%$ of them voted in favor (Ray 2013).

The Moroccan case illustrates a situation of positive institutional spillovers when facing neighboring fragility. It suggests that due to the specific religious legitimacy of King Mohammed VI as "Commander of all Believers" in Moroccan culture, the spillover effects of the Arab Spring on challengers' opportunity cost of conflict were limited. That left some space for the state to solve the issue peacefully by some investment in more inclusive institutions.

Interestingly, Morocco is experiencing right now ongoing protests sparked by the death on October 282016 of the fish vendor Mouhcine Fikri, crushed to death in a rubbish truck while attempting to retrieve the fish that the local police had confiscated. Given the popular discontent associated to a struggling economy, high youth unemployment, and the fact that despite the apparent concessions to popular demand, the monarchy in fact seemed not to have ceded much of its essential prerogatives (Maghraoui, 2011; Benchemsi, 2012; Ray, 2013; Verlin, 2015), some analysts have started to speculate that Morocco might be currently on the verge of a second Arab Spring. Others suggest however that the specificity of the Moroccan situation and the political reforms undertaken so far may prevent a destabilization of the regime (Yerkes, 2016). While the outcome of the current social dynamics is still uncertain, these events put to the test whether the institutional reforms undertaken by King Mohammed VI have been just a "smokescreen" to dodge popular discontent, or significant enough to deter the diffusion of widespread civil unrest in the country. 


\section{Conclusion}

This paper has introduced a simple theoretical model to analyze some key issues in the emergence of regional clusters of civil conflicts. In our framework, A "Merchant of Death" actor sells war inputs to rebel groups and benefits from the weak territorial control of the state in a porous frontier. A market size effect on the market for violence generates spillovers of civil war in neighboring countries through that porous border. These spillovers induce complementarity effects across policy regimes and institution building across countries in the region. As our analysis has shown, this leads to endogenous spatial clusterings of civil wars that depend not only on observable fundamentals, but also on more intangible belief formation processes at the regional level. In this context, we discussed how a government may protect itself by investing in better institutions at home, as was the example of Morocco during the Arab Spring, and we investigated the rationale for foreign intervention through direct military intervention, military support or institutional cooperation, to help avoid regional destabilization from weak neighbors.

The paper provides theoretical grounds for the existence of regional conflict complexes and spatial clustering of civil wars. It also paves the way for extensions and future research on several dimensions. First of all, we emphasized one specific source of cross-border spillovers: a size effect associated with the existence of a market for war inputs operating in the porous border. The conflict literature also highlights other vectors of the diffusion of civil wars such as ethnic cross-border ties, ${ }^{29}$ regional population displacements and refugee camps, ${ }^{30}$ their cross-interactions ${ }^{31}$ and their interactions with the market for violence. ${ }^{32}$ Extensions of our framework to these specific dimensions may therefore be useful to deepen our understanding of the transmission mechanisms of civil conflicts and to derive interesting new empirical and policy implications.

Second, from an empirical point of view, our analysis uncovers an important endogeneity issue in the contagion of civil conflicts. The cross-border feedback effects associated with neighboring civil wars mean that it may actually be difficult to have a relevant definition of what a domestic conflict is, as almost all violence related to what is called a civil war may in some sense have some external dimension. This suggests that

\footnotetext{
${ }^{29}$ For instance, the importance of cross-border ethnic networks in the diffusion of conflict has been highlighted by Gleditsch (2007); Forsberg (2014); Salehyan (2011); Weidmann (2015). Recently Bosker $\&$ de Ree (2014) estimate that ethnic links to a neighboring country involved in an ethnic civil war increase the probability of an outbreak of ethnic civil war at home by 6 percentage points. See Rüegger (2013a) for a survey.

${ }^{30}$ see Adelman (1998); Salehyan \& Gleditsch (2006); Rüegger (2013b). Ansorg (2011) provides a survey of the literature.

${ }^{31}$ Michalopoulos \& Papaioannou (2016) show that partitioned ethnic groups have a lower opportunity cost of conflict and facilitate population displacements across the border.

${ }^{32}$ Rüegger (2013a) and Camarena (2016) provide recent evidence on how refugee camps may also extend the networks of rebel groups and enable the transnational diffusion of combatants, weapons and ideologies.
} 
one should think about developing empirical models analyzing spatial conflict clustering as occurrences of regional complexes rather than unidirectional processes of spatial diffusion. ${ }^{33}$

Our model provides a theoretical basis to unify policy responses to fragility abroad. One interesting prediction that would deserve further policy attention is the fact that to avoid a civil war in a neighboring country, a government may improve the terms of trade for the potential challenger. Another feature of our set-up is identifying an array of different strategies to address a source of regional instability. What are the different trade-offs across these instruments? Why is it that, as we documented in the case of AQIM, different actors seem to pursue different strategies for a single conflict? While this is beyond the scope of our paper, we hope that the framework developed here can be a stepping stone to understand these issues.

Since our analysis focuses on the contagion of conflict, the only motivation for neighboring states to intervene in domestic affairs is to stabilize the country and de-escalate conflicts. This does not exhaust the list of motivations for foreign interventions. In particular, foreign governments have been documented to support rebel groups and actively attempt to destabilize neighboring regimes. ${ }^{34}$ Since this would tend to destabilize the country, and exacerbate conflicts (Karlén, 2017), such a move would rest on another motivation than the one we have considered in this paper. One possibility is the fact that the rebel group transfers back to the supporting government part of the rents obtained in the civil conflict in the neighboring country. This would be especially true if the neighboring country is resource-rich and that the supporting government does not want or cannot take the risk an open military conflict with its neighbor to grab the resource. Another motivation may be the fact that a government will support a foreign rebel group as a way to increase his own political legitimacy at home, getting in particular political support from domestic ethnic groups affiliated to the rebel group across the border. The government would then face a trade off between the gains of increased domestic political support against the destabilization cost of a potential regional contagion of the conflict. Foreign governments that are strong enough to be immune to the threat of contagion, or on the contrary starving for domestic legitimization, are likely to adopt such a strategy. Developing a full analysis of these dimensions is clearly beyond the scope of this paper. We hope however that our framework can be a stepping stone for an understanding of

\footnotetext{
${ }^{33}$ This is consistent with the view expounded by Gersovitz \& Kriger (2013), who criticize the current econometric approaches to analyze the spatial and temporal patterns of civil wars, and rather advocate the use of the historical comparative methods and the concept of a regional war complex as promising ways forward in the study of large-scale violence.

${ }^{34}$ For instance, Kausch (2017) mentions the Iranian support of Hezbollah, Qatari support of the Muslim Brotherhood (Ikhwan) and U.S. and Russian support of the Kurds. Rohner et al. (2013) mention that Sudan provided a safe haven for the Lord's Resistance Army, a Ugandan rebel group, and Martínez (2017) that Venezuela provided a safe haven for the Colombian group FARC. McKnight (2015) and König et al. (2017) study Ugandan and Rwandan involvement in the so-called first and second Congo wars in DRC. San-Akca (2016) takes a more systematic approach to the issue.
} 
these interesting issues.

\section{Appendix [For Online Publication]}

\section{A Characterization of the political equilibrium regimes for a given country}

To characterize the political equilibrium regime in the country, we first consider the optimal peaceful contract and then compare such contract to the civil war outcome. The optimal peaceful contract is the solution of a simple linear programming problem and is characterized by the following lemma:

Lemma 2 Assume an investment I by the non-state actor, and define

$$
\bar{\theta}(I, \alpha)=\frac{\Gamma(I)-\alpha \bar{M}}{R+N_{G}-\bar{M}} .
$$

The optimal peaceful contract for the government is given by:

1. If $\alpha<1$ and $\theta \geq \bar{\theta}(I, \alpha)$, then $M_{G}=\bar{M}$ and $T=(\Gamma(I)-\alpha \bar{M}) / \theta$.

2. If $\Gamma(I) /\left(R+N_{G}\right) \leq \alpha<1$ and $\theta<\bar{\theta}(I, \alpha)$ then $M_{G}=\left(\Gamma(I)-\theta\left(R+N_{G}\right)\right) /(\alpha-\theta)$ and $T=\left(\alpha\left(R+N_{G}\right)-\Gamma(I)\right) /(\alpha-\theta)$.

3. If $\alpha>1$ then $M_{G}=\max [\bar{M}, \Gamma(I) / \alpha]$ and $T=0$.

Proof: Both the opportunity cost for the government and the benefit for the rebel group of a unit of transfer $T$ is $\theta$, because the government may renege with a probability $1-\theta$. The marginal opportunity cost of military spending is 1 for the government, but matching an increase of one unit of military spending $M_{G}$ would cost the rebel group $\alpha$. To deter a rebellion, the government would therefore rather resort to transfers when $\alpha<1$, and to military spending when $\alpha>1$.

When $\alpha<1$, the government may not be in a position to credibly replace all military spending by a transfer: it cannot commit beyond the budget constraint (BC). When institutions are good enough (ie. $\theta \geq \bar{\theta}(I, \alpha)$ ), then any unit of military spending above the minimum $\bar{M}$ can be advantageously replaced by $\alpha$ unit of transfer. When institutions are not good enough, the state would like to resort to transfers instead of military spending, but it cannot promise transfers beyond its resources.

Finally, notice that for $\alpha<\Gamma(I) /\left(R+N_{G}\right)$ and $\theta<\bar{\theta}(I, \alpha)$, there is no feasible contract that allows the government to achieve a peaceful outcome. $Q E D$. 
To determine whether we are in a peaceful regime or that civil war emerges, we compute the indirect payoffs of the government in the different regimes. These are given as follows:

1. [Redistributive regime] $V_{G}=N_{G}+R-\Gamma(I)-(1-\alpha) \bar{M}$

2. [Repressive regime] $V_{G}=(1-\theta) \frac{\alpha\left(N_{G}+R\right)-\Gamma(I)}{\alpha-\theta}$

3. [Prætorian regime] $V_{G}=N_{G}+R-M_{G}$

4. [Civil war] $V_{G}=N_{G}-\bar{M}+c(I)$

A simple comparison of the payoffs reveals that a peace regime is always better than civil war for the government when this is implemented either as a redistributive regime or as a prætorian regime. However, it may not be always the case that the government prefers a repressive regime to civil war. It prefers civil war if and only if

$$
\theta<\underline{\theta}(I, \alpha)=\frac{\Gamma(I)-\alpha(R+\bar{M}-c(I))}{N_{G}-\bar{M}-\alpha\left(N_{G}+R\right)+\Gamma(I)+c(I)}
$$

$\underline{\theta}$ decreases with $\alpha$ and $\bar{M}$, and increases with $R$. A higher ability for the government to commit and a larger opportunity cost of fighting help reaching a peaceful solution. A larger government's military advantage makes it also easier to achieve peace. Likewise, in line with the literature emphasizing the role of "incentives" or "greed", larger civil conflict stakes makes it less likely to get the peaceful outcome more difficult to achieve. Finally, the larger the supply of war inputs to rebels, the more likely a civil war is to prevail.

In the space $(\alpha, \theta)$, the formal characterization of the political equilibrium regimes corresponds therefore to figure (1) in the main text. They can be formally described in the following proposition:

Proposition 4 1. [redistributive regime] if $\alpha<1$ and $\theta \geq \bar{\theta}(I, \alpha)$ then $M_{G}=\bar{M}$, $M_{C}=0, T=(\Gamma(I)-\alpha \bar{M}) / \theta$ and $V_{G}=N_{G}+\Gamma(I)-(1-\alpha) \bar{M}$.

2. [repressive regime] if $\Gamma(I) /\left(R+N_{G}\right) \leq \alpha<1$ and $\underline{\theta}(I, \alpha) \leq \theta<\bar{\theta}(I, \alpha)$, then $M_{G}=\left(\Gamma(I)-\theta\left(R+N_{G}\right)\right) /(\alpha-\theta), M_{C}=0, T=\left(\alpha\left(R+N_{G}\right)-\Gamma(I)\right) /(\alpha-\theta)$ and $V_{G}=(1-\theta)\left(\alpha\left(N_{G}+R\right)-\Gamma(I)\right) /(\alpha-\theta)$.

3. [prætorian regime] if $\alpha \geq 1$, then $M_{G}=\max [\bar{M}, \Gamma(I) / \alpha], M_{C}=0, T=0$ and $V_{G}=N_{G}+R-M_{G}$

4. [civil war] if $\theta<\min [\underline{\theta}(\alpha), \bar{\theta}(\alpha)]$, then $M_{G}=\bar{M}, M_{C}=\gamma \bar{M}, T=0$ and $V_{G}=$ $N_{G}-\bar{M}+c(I)$. 
Because $\Gamma$ is an increasing function of $I$, it is immediate from to see from (9) that $\bar{\theta}(I, \alpha)$ is an increasing function of $I$.

Now

$$
\underline{\theta}(I, \alpha)=\frac{\Gamma(I)-\alpha(R+\bar{M}-c(I))}{N_{G}-\bar{M}-\alpha\left(N_{G}+R\right)+\Gamma(I)+c(I)}
$$

and differentiation shows that the sign of $\partial \underline{\theta} / \partial I$ is the same as the sign of

$$
\begin{aligned}
\Omega= & \left(\Gamma^{\prime}+\alpha c^{\prime}\right) \cdot\left(N_{G}-\bar{M}-\alpha\left(N_{G}+R\right)+\Gamma+c\right) \\
& -\left(\Gamma^{\prime}+c^{\prime}\right) \cdot(\Gamma-\alpha(R+\bar{M}-c))
\end{aligned}
$$

which can be rewritten as

$$
\begin{aligned}
\Omega= & \left(\Gamma^{\prime}+\alpha c^{\prime}\right) \cdot(\Gamma+c)+\left(\Gamma^{\prime}+\alpha c^{\prime}\right) \cdot\left(N_{G}-\bar{M}-\alpha\left(N_{G}+R\right)\right) \\
& -\left(\Gamma^{\prime}+c^{\prime}\right) \cdot(\Gamma+\alpha c)+\left(\Gamma^{\prime}+c^{\prime}\right) \alpha(R+\bar{M})
\end{aligned}
$$

or

$$
\begin{aligned}
\Omega & =(1-\alpha)\left(\Gamma^{\prime} c-\Gamma c^{\prime}\right)+\left(\Gamma^{\prime}+\alpha c^{\prime}\right)\left(N_{G}-\bar{M}-\alpha\left(N_{G}+R\right)\right)+\left(\Gamma^{\prime}+c^{\prime}\right) \alpha(R+\bar{M}) \\
& =(1-\alpha)\left[\left(\Gamma^{\prime} c-\Gamma c^{\prime}\right)+\Gamma^{\prime}\left(N_{G}-\bar{M}\right)+\alpha c^{\prime}\left(N_{G}+R\right)\right]
\end{aligned}
$$

Now

$$
\left(\Gamma^{\prime} c-\Gamma c^{\prime}\right)+\Gamma^{\prime}\left(N_{G}-\bar{M}\right)+\alpha c^{\prime}\left(N_{G}+R\right)=\Gamma^{\prime}\left(c+N_{G}-\bar{M}\right)-c^{\prime} \cdot\left(\Gamma-\alpha\left(N_{G}+R\right)\right)
$$

Given that $\alpha<\frac{\Gamma}{R+\bar{M}-c}$ in the range where $\underline{\theta}(I, \alpha)>0$, and that $c^{\prime}<0$, this is larger than

$$
\Gamma^{\prime}\left(c+N_{G}-\bar{M}\right)-\alpha c^{\prime} \cdot\left(\bar{M}-c-N_{G}\right)=\left(c+N_{G}-\bar{M}\right)\left(\Gamma^{\prime}-\alpha c^{\prime}\right)>0
$$

as $\left(c+N_{G}-\bar{M}\right)>0, \Gamma^{\prime}>0$ and $c^{\prime}<0$.

Hence at the border between the repressive regime and civil war (e.g. the range of $\alpha$ such that $\alpha>\frac{\Gamma}{R+N_{G}}$ and $\left.\underline{\theta}(I, \alpha)>0\right)$, one gets that $\partial \underline{\theta} / \partial I>0$ and $\underline{\theta}(I, \alpha)$ is increasing in $I$. $Q E D$.

\section{B Extension: monopolistic competition on the market for war inputs}

The bundle of war inputs that enters into the probability of a revolution being successful is assumed to be supplied by a global monopoly weapon broker in the main text. In this 
extension, we envisage monopolistic competition between various underground actors (local craft producers and warlords, organized mafias, cross-border ethnic communities) who provide differentiated and imperfectly substitutable war inputs, according to the formula:

$$
W=\left(\sum_{i=1}^{i=n} w_{i}^{\frac{\sigma-1}{\sigma}}\right)^{\frac{\sigma}{\sigma-1}} \text { and } \sigma>1
$$

where $w_{i}$ is an input provided by a non-state actor $i \in(1, \ldots n)$ and $W$ is a aggregate index of conflict efficiency. We assume that underground suppliers are in monopolistic competition on the market for war inputs, each of them producing one differentiated input, with the same technology with marginal cost $c$ and a fixed cost of entry $F$. We normalize $c=\frac{\sigma-1}{\sigma}$ for convenience.

If there is a conflict, the sequence of events should be envisaged as follows:

1. $n$ underground actors decide to enter to propose war inputs $w_{i}$ and compete monopolistically.

2. The rebels buy the war inputs that maximize their expected payoffs, at a cost $\sum_{i} p_{i} w_{i}$.

The demand for each war input supplied by a underground actor is then given by:

$$
w_{i}=w\left(p_{i}\right)=W\left(R\left(1-\pi_{0}\right) e^{-W} / p_{i}\right)^{\sigma}
$$

Given the symmetry of the problem, we consider symmetric Nash equilibria in monopolistic prices: a given underground actor chooses his optimal price to maximize

$$
\max _{p_{i}} w\left(p_{i}\right)\left(p_{i}-c\right)-F
$$

whose solution gives the equilibrium price $p_{i}=p=\frac{\sigma}{\sigma-1} c=1$. From this we obtain the input demand $w_{i}=w=W\left(R\left(1-\pi_{0}\right) e^{-W}\right)^{\sigma}$ and the efficiency index of war $W=$ $n^{\frac{\sigma}{\sigma-1}} w=\ln \left(R\left(1-\pi_{0}\right)\right)+\ln (n) /(\sigma-1)$. The equilibrium probability of a rebellion being successful is

$$
\pi(W(n))=1-n^{-\frac{1}{\sigma-1}} / R
$$

The likelihood of a rebellion being successful increases with the number of underground actors $n$ and the size of the contested resource $R .{ }^{35}$ Under conflict, the expected utility of the rebels can therefore be written:

\footnotetext{
${ }^{35}$ We assume that $R$ is large enough for such probabillity to be always positive ( $R \geq 1$ is a sufficient condition for that).
} 


$$
U_{C}=a\left(N_{C}-\frac{M_{G}}{\gamma}\right)+R-\Gamma(n)
$$

where $\Gamma(n)=n^{-\frac{1}{\sigma-1}}\left(1+\ln \left(R\left(1-\pi_{0}\right)\right)+\ln (n) /(\sigma-1)\right)$ is a decreasing function of $n .^{36}$

The situation is exactly the same as in the main text, with $\Gamma(I) \equiv R-\Gamma(n)$ and $c(I) \equiv n^{-\frac{1}{\sigma-1}}$. To obtain the market size effect on the market for war inputs, it is convenient to assume free entry on the market for violence. This determines an equilibrium number of underground actors, each supplying a unique war input, in the two situations we wish to compare, namely when rebellion touches one only country or both countries simultaneously. To simplify notations, $n$ will designate by default the equilibrium number of underground actors when one country is in a civil war, so respectively $n^{A}$ and $n^{B}$ for countries $A$ and $B . n^{A B}$ will designate the equilibrium of underground actors in the porous frontier when both countries are in a civil war.

Consider first the case of one country in isolation. The free entry condition in such a case can be written $w(p-c)=F$, which yields $w=\sigma F$. To ensure that free entry provides an equilibrium, the contestable resource $R$ must be large enough, ie. $R\left(1-\pi_{0}\right)>e^{\sigma F}$. We assume that this is the case thereafter. Going back to the expression of the efficiency index, the equilibrium number of war inputs $n$ is then uniquely determined by the equation

$$
n^{\frac{\sigma}{\sigma-1}} \sigma F=\ln \left(R\left(1-\pi_{0}\right)\right)+\frac{\ln (n)}{\sigma-1}
$$

Thanks to the implicit function theorem, we can write $n$ as a function $n=n\left(R, F, \pi_{0}\right)$, which is increasing in $R$, and decreasing in $F$ and in $\pi_{0} \cdot{ }^{37}$ Notice that in equilibrium, $\Gamma(n)=n^{-\frac{1}{\sigma-1}}+\sigma F n$, which also simplifies the expression of $\underline{\theta}$.

Suppose now our setting with two countries $A$ and $B$ with both rebel groups engaged in a civil war with their respective government; In such a case, the underground sector sells their war inputs to both groups through the porous frontier. The supply of war inputs is now determined by the free entry condition in the porous frontier. In equilibrium, $n^{A B}$ is therefore given by:

$$
\left(n^{A B}\right)^{\frac{\sigma}{\sigma-1}} \sigma F=\sum_{i} \ln \left(R^{i}\left(1-\pi_{0}^{i}\right)\right)+\frac{2 \ln \left(n^{A B}\right)}{\sigma-1}
$$

Comparing this to Eq. 13 shows that $n^{A B}$ is larger than both $n^{A}$ and $n^{B} .{ }^{38}$ When

\footnotetext{
${ }^{36}$ Formally, it is so iff $n^{\frac{1}{\sigma-1}} R\left(1-\pi_{0}\right)>1$. Such a restriction ensures that war inputs are useful (ie. $W(n)>0)$ and $\pi(W(n))>\pi_{0}$.

${ }^{37}$ When $R$ is large enough (ie. $\left.\ln R\left(1-\pi_{0}\right)>\frac{\ln (\sigma F)}{\sigma-1}+(\sigma F)^{-\frac{1}{\sigma-1}}\right)$ it is easy to see that $n\left(R, F, \pi_{0}\right) \sigma F>1$.

${ }^{38}$ Both sides of both equations are increasing functions of $n$. The left-hand side is convex, and both right-hand sides are concave. For any value of $n \geq 1$, the right-hand side of Eq. 14 is larger than that of Eq. 13. This means that $n^{A B}$ is larger than both $n^{A}$ and $n^{B}$.
} 
both countries are in conflict, there is a larger demand for war inputs and therefore more entry of underground actors to provide such inputs. We see that this richer setup yields the same conclusions as our simpler assumption of a monopoly weapon broker.

\section{References}

Acemoglu, D., Johnson, S., \& Robinson, J. A. (2001). The colonial origins of comparative development: An empirical investigation. American Economic Review, 91(5), 1369-401.

Adelman, H. (1998). Why refugee warriors are threats. Journal of Conflict Studies, $18(1)$.

Anselin, L. \& O'Loughlin, J. (1992). Geography of international conflict and cooperation: spatial dependence and regional context in Africa. In D. Ward (Ed.), The New Geopolitics chapter 3, (pp. 39-75). Gordon and Breach.

Ansorg, N. (2011). How does militant violence diffuse in regions? regional conflict systems in international relations and peace and conflict studies. International Journal of Conflict and Violence, 5(1), 173-87.

Armstrong, A. \& Rubin, B. R. (2005). The Great Lakes and South Central Asia. In S. Chesterman, M. Ignatieff, \& R. Thakur (Eds.), Making States Work.

Azam, J.-P. (2006). The paradox of power reconsidered: A theory of political regimes in Africa. Journal of African Economies, 15(1), 26-58.

Ban, K. (2012). Report of the assessment mission on the impact of the Libyan crisis on the Sahel region. Report, United Nations Security Council.

Bazzi, S. \& Blattman, C. (2014). Economic shocks and conflict: Evidence from commodity prices. American Economic Journal: Macroeconomics, 6(4), 1-38.

Benchemsi, A. (2012). Morocco: outfoxing the opposition. Journal of Democracy, 23(1), 57-69.

Besley, T. \& Ghatak, M. (2010). Property rights and economic development. In D. Rodrik \& M. Rosensweig (Eds.), Development Economics, volume 5 (pp. 4525-95). North-Holland.

Besley, T. \& Persson, T. (2008). Wars and state capacity. Journal of the European Economic Association, 6(2/3), 522-30.

Besley, T. \& Persson, T. (2009). The origins of state capacity: Property rights, taxation, and politics. American Economic Review, 99(4), 1218-44.

Besley, T. \& Persson, T. (2010). State capacity, conflict, and development. Econometrica, 78(1), 1-34.

Bichler, G. \& Malm, A. (2013). Small arms, big guns: a dynamic model of illicit market opportunity. Global Crime, 14(2-3), 261-86.

Black, N. (2013). When have violent civil conflicts spread? Introducing a dataset of substate conflict contagion. Journal of Peace Research, 50(6), 751-9. 
Blattman, C. \& Miguel, E. (2010). Civil war. Journal of Economic Literature, 48(1), 3-57.

Böhnke, J. R. \& Zürcher, C. (2013). Aid, minds and hearts: The impact of aid in conflict zones. Conflict Management and Peace Science, 30(5), 411-32.

Bosker, M. \& de Ree, J. (2014). Ethnicity and the spread of civil war. Journal of Development Economics, 108, 206-21.

Bourguignon, F. \& Verdier, T. (2009). The political economy of state capacity building and redistribution in elite dominated societies. Working paper.

Bove, V., Gleditsch, K. S., \& Sekeris, P. G. (2016). Oil above water. Journal of Conflict Resolution, 60(7), 1251-77.

Braithwaite, A. (2006). The geographic spread of militarized disputes. Journal of Peace Research, 43(5), 507-22.

Braithwaite, A. (2010). Resisting infection: How state capacity conditions conflict contagion. Journal of Peace Research, 47(3), 311-9.

Brewer, J. (1989). The Sinews of Power: War, Money and the English State, 1688-1783. Unwin Hyman.

Buhaug, H. \& Gleditsch, K. S. (2008). Contagion or confusion? Why conflicts cluster in space. International Studies Quarterly, 52(2), 215-33.

Buzan, B. \& Wæver, O. (2003). Regions and Power: the Structure of International Security. Cambridge University Press.

Camarena, K. R. (2016). Returning Home and Worsening the War: The Causal Effect of Refugee Return on Civil Conflict Intensity. mimeo.

Cárdenas, M. \& Tuzemen, D. (2011). Under-investment in state capacity: the role of inequality and political instability. Research Working Paper RWP 11-07, Federal Reserve Bank of Kansas City.

Chauvet, L. \& Collier, P. (2004). Development Effectiveness in Fragile States: Spillovers and Turnarounds. Technical report, Center for the Study of African Economies, Oxford.

Collier, P. \& Hoeffler, A. (2004). Greed and grievance in civil war. Oxford Economic Papers, 56(4), 563-95.

Cunningham, D. E., Gleditsch, K. S., \& Salehyan, I. (2013). Non-state actors in civil wars: A new dataset. Conflict Management and Peace Science, 30(5), 516-31.

Cunningham, D. E., Gleditsch, K. S., \& Salehyan, I. (2016). Non-state actors in civil war. In D. A. Backer, R. Bhavnani, \& P. K. Huth (Eds.), Peace and Conflict 2016. Routledge.

Dalacoura, K. (2012). The 2011 uprisings in the Arab Middle East: political change and geopolitical implications. International Affairs, 88(1), 63-79.

DCAF \& Geneva Call (2011). Armed Non-State Actors: Current Trends \& Future Challenges. DCAF Horizon 2015 Working Paper 5. 
De Long, J. B. \& Shleifer, A. (1993). Princes and merchants: European city growth before the industrial revolution. Journal of Law and Economics, 36(2), 671-702.

DiCarlo, R. A. (2012). Remarks by Ambassador Rosemary DiCarlo, U.S. Deputy Permanent Representative to the United Nations, at Security Council Briefing on Peace and Security in Africa. United Nations.

Elbadawi, I. \& Sambanis, N. (2002). How much war will we see? explaining the prevalence of civil war. Journal of Conflict Resolution, 46(3), 307-34.

Fearon, J. D. \& Laitin, D. D. (2003). Ethnicity, insurgency, and civil war. American Political Science Review, 97(1), 75-90.

Findley, M. G. \& Teo, T. K. (2006). Rethinking third-party interventions into civil wars: An actor-centric approach. The Journal of Politics, 68(4), 828-37.

Forsberg, E. (2014). Transnational transmitters: Ethnic kinship ties and conflict contagion 1946-2009. International Interactions, 40(2), 143-65.

Gersovitz, M. \& Kriger, N. (2013). What is a civil war? A critical review of its definition and (econometric) consequences. The World Bank Research Observer, 28(2), 159-90.

Gleditsch, K. S. (2002). All International Politics Is Local: The Diffusion of Conflict, Integration, and Democratization. University of Michigan Press.

Gleditsch, K. S. (2007). Transnational dimensions of civil war. Journal of Peace Research, 44(3), 293-309.

Gleditsch, K. S. (2009). The spread of civil war. In J. Bercovitch, V. Kremenyuk, \& W. Zartman (Eds.), The SAGE Handbook of conflict resolution (pp. 595-612). Sage.

Hegre, H., Ellingsen, T., Gates, S., \& Gleditsch, N. P. (2001). Towards a democratic civil peace? American Political Science Review, 95, 33-48.

Hegre, H. \& Sambanis, N. (2006). Sensitivity analysis of empirical results on civil war onset. Journal of Conflict Resolution, 50(4), 508-35.

Hübschle, A. (2011). From theory to practice: Exploring the organized crime-terror nexus in Sub-Saharan Africa. Perspectives on Terrorism, 5(3-4), 81-95.

Joffé, G. (2011). The Arab Spring in North Africa: origins and prospects. The Journal of North African Studies, 16(4), 507-32.

Jones, E. (1981). The European miracle: environments, economies and geopolitics in the history of Europe and Asia. Cambridge University Press.

Karlén, N. (2017). The legacy of foreign patrons: External state support and conflict recurrence. Journal of Peace Research, 54(4), 499-512.

Kathman, J. D. (2010). Civil war contagion and neighboring interventions. International Studies Quarterly, 54(4), 989-1012.

Kathman, J. D. (2011). Civil war diffusion and regional motivations for intervention. Journal of Conflict Resolution, 55(6), 847-76.

Kausch, K. (2017). Proxy agents: state and non-state alliances in the Middle-East. In L. Kamel (Ed.), The frailty of authority: Borders, non-state actors and power vacuums in a changing Middle-East (pp. 67-84). Edizioni Nuova Cultura. 
Keohane, R. (1984). After Hegemony: Cooperation and Discord in the World Political Economy. Princeton University Press.

Koga, J. (2011). Where do third parties intervene? Third parties' domestic institutions and military interventions in civil conflicts. International Studies Quarterly, 55(4), 1143-66.

König, M. D., Rohner, D., Thoenig, M., \& Zilibotti, F. (2017). Networks in conflict: Theory and evidence from the great war of Africa. Econometrica, 85(4), 1093-132.

Lemke, D. (2002). Regions of War and Peace. Cambridge University Press.

Levi, M. (1988). Of Rule and Revenue. California series on social choice and political economy. University of California Press.

Maggi, G. \& Rodriguez-Clare, A. (1998). The value of trade agreements in the presence of political pressures. Journal of Political Economy, 106(3), 574-601.

Maghraoui, D. (2011). Constitutional reforms in morocco: between consensus and subaltern politics. The Journal of North African Studies, 16(4), 679-99.

Mansfield, E. D. \& Pevehouse, J. C. (2006). Democratization and international organizations. International Organization, 60(1), 137-67.

Martínez, L. R. (2017). Transnational insurgents: Evidence from colombia's FARC at the border with chávez's venezuela. Journal of Development Economics, 126, 138-53.

May, C. (2017). Transnational Crime and the Developing World. report, Global Financial Integrity.

McBride, M., Milante, G., \& Skaperdas, S. (2011). Peace and war with endogenous state capacity. Journal of Conflict Resolution, 55(3), 446-68.

McKnight, S. (2015). The rise and fall of the Rwanda-Uganda alliance (1981-1999). African Studies Quarterly, 15(2).

Michalopoulos, S. \& Papaioannou, E. (2014). National institutions and subnational development in Africa. The Quarterly Journal of Economics, 129(1), 151-213.

Michalopoulos, S. \& Papaioannou, E. (2016). The long-run effect of the scramble for Africa. American Economic Review, 106(7), 1802-48.

Mincheva, L. G. \& Gurr, T. R. (2010a). Unholy alliances: Evidence on linkages between trans-state terrorism and crime networks: The case of Bosnia. In W. Benedek, C. Daase, V. Dimitrijević, \& P. V. Duyne (Eds.), Transnational Terrorism, Organized Crime and Peace-Building (pp. 190-206). Palgrave Macmillan UK.

Mincheva, L. G. \& Gurr, T. R. (2010b). Unholy alliances: How trans-state terrorism and international crime make common cause. In R. Reuveny \& W. R. Thompson (Eds.), Coping with Terrorism: Origins, Escalation, Counterstrategies, and Responses. SUNY Press.

Mincheva, L. G. \& Gurr, T. R. (2013). Crime-Terror Alliances and the State. Routledge.

Moreno-Torres, M. \& Anderson, M. (2004). Fragile States: Defining Difficult Environments for Poverty Reduction. PRDE working paper 1, DFID. 
OECD (2004). DAC experts meeting on peace-building and development in the Democratic Republic of Congo in the context of the region of Central Africa. Accessed July 7th, 2016.

Picciotto, R., Alao, C., Ipke, E., Kimani, M., \& Slade, R. (2005). Striking a New Balance: Donor Policy Coherence and Development Cooperation in Difficult Environments. The International Policy Institute at Kings College London and The Global Policy Project.

Ray, B. (2013). The Arab Spring and Morocco's reforms: heading for an overhaul or an overthrow? Technical report, Osgood Center. retrieved on 09/27/2017 from http://osgoodcenter.org/Betsy.pdf.

Regan, P. M. (1998). Choosing to intervene: Outside interventions in internal conflicts. The Journal of Politics, 60(3), 754-79.

Regan, P. M. (2000). Civil Wars and Foreign Powers: Outside Intervention in Intrastate Conflict. University of Michigan Press.

Regan, P. M. (2002). Third-party interventions and the duration of intrastate conflicts. Journal of Conflict Resolution, 46(1), 55-73.

Rohner, D., Thoenig, M., \& Zilibotti, F. (2013). Seeds of distrust: conflict in Uganda. Journal of Economic Growth, 18(3), 217-52.

Rubin, B. R. (2001). Regional Approaches to Conflict Management in Africa. IPA seminar report, Permanent Mission of Colombia to the United Nations and International Peace Academy. Retrieved November 14th, 2016.

Rubin, B. R. (2006). Peace building and state-building in Afghanistan: Constructing sovereignty for whose security? Third World Quarterly, 27(1), 175-85.

Rüegger, S. (2013a). Conflict Actors in Motion: Refugees, Rebels and Ethnic Groups. $\mathrm{PhD}$ thesis, ETH Zürich.

Rüegger, S. (2013b). Refugee Flows, Transnational Ethnic Linkages and Conflict Diffusion: Evidence from the Kosovo Refugee Crisis. Paper prepared for presentation at the RRPP annual conference, Belgrade, Serbia, May 24-26, 2013.

Salehyan, I. (2011). Rebels without Borders: Transnational Insurgencies in World Politics. Cornell University Press.

Salehyan, I. \& Gleditsch, K. S. (2006). Refugees and the spread of civil war. International Organization, 60(2), 335-66.

Sambanis, N. (2002). A review of recent advances and future directions in the quantitative literature on civil war. Defence and Peace Economics, 13(3), 215-43.

San-Akca, B. (2016). States in disguise: cause of state support for rebel groups. Oxford University Press.

Seniora, J. \& Poitevin, C. (2010). Managing Land Borders and the Trafficking of Small Arms and Light Weapons. GRIP report 2010/3, Groupe de Recherche et d'Intervention sur la Paix et la Sécurité. 
Sougane, A., Tounkara, M., Traore, S. M., Razafindrakoto, M., \& Roubaud, F. (2015). Dynamique de la Gouvernance, la paix et la Sécurité au Mali entre 2014 et 2015 : Une analyse à partir des modules GPS-SHaSA. Report, DIAL-UNDP.

Stimson Center (2016). Beyond the 'merchants of death': The mechanics of arms trafficking from the united states. Panel discussion at the Stimson Center, Washington D.C.

Tilly, C. (1985). War making and state making as organized crime. In P. B. Evans, D. Rueschemeyer, \& T. Skocpol (Eds.), Bringing the State Back In chapter 5, (pp. 149-91). Cambridge University Press.

Vallings, C. \& Moreno-Torres, M. (2005). Drivers Of Fragility: What Makes States Fragile? PRDE Working Papers 7, DFID.

Vargas Meza, R. (2011). USAID's Alternative Development policy in Colombia: A critical analysis. Drug policy briefing 38, Transnational Institute.

Verlin, P. (2015). Morocco and the Arab Spring. Sigma Iota Rho Journal of International Relations. retrieved on 09/27/2017 from http://www.sirjournal.org/blogs/2015/2/26/morocco-and-the-arab-spring.

Weidmann, N. B. (2015). Communication networks and the transnational spread of ethnic conflict. Journal of Peace Research, 52(3), 285-96.

Wolff, S. (2010). The regional dimensions of state failure. Review of International Studies, 37(3), 951-72.

Yerkes, S. (2016). Why Morocco's protests won't usher in another Arab Spring. Technical report, Brookings. Retrieved on 09/27/2017 from https://www.brookings.edu/blog/markaz/2016/11/02/why-moroccos-protestswont-usher-in-another-arab-spring/.

Zohar, E. (2014). How Rebellious Non-State-Actors acquire weapons. PhD thesis, The University of Otago (NZ). 